\title{
Functional selectivity of adenosine receptor ligands
}

\author{
Dennis Verzijl • Ad P. IJzerman
}

Received: 24 March 2011 / Accepted: 5 April 2011 / Published online: 5 May 2011

(C) The Author(s) 2011. This article is published with open access at Springerlink.com

\begin{abstract}
Adenosine receptors are plasma membrane proteins that transduce an extracellular signal into the interior of the cell. Basically every mammalian cell expresses at least one of the four adenosine receptor subtypes. Recent insight in signal transduction cascades teaches us that the current classification of receptor ligands into agonists, antagonists, and inverse agonists relies very much on the experimental setup that was used. Upon activation of the receptors by the ubiquitous endogenous ligand adenosine they engage classical $G$ protein-mediated pathways, resulting in production of second messengers and activation of kinases. Besides this well-described G protein-mediated signaling pathway, adenosine receptors activate scaffold proteins such as $\beta$-arrestins. Using innovative and sensitive experimental tools, it has been possible to detect ligands that preferentially stimulate the $\beta$-arrestin pathway over the $G$ protein-mediated signal transduction route, or vice versa. This phenomenon is referred to as functional selectivity or biased signaling and implies that an antagonist for one pathway may be a full agonist for the other signaling route. Functional selectivity makes it necessary to redefine the functional properties of currently used adenosine receptor ligands and opens possibilities for new and more selective ligands. This review focuses on the current knowledge of functionally selective adenosine receptor ligands and on $\mathrm{G}$ protein-independent signaling of adenosine receptors through scaffold proteins.
\end{abstract}

D. Verzijl · A. P. IJzerman $(\bowtie)$

Division of Medicinal Chemistry,

Leiden/Amsterdam Center for Drug Research, Leiden University,

PO Box 9502, 2300 RA Leiden, The Netherlands

e-mail: ijzerman@lacdr.leidenuniv.nl
Keywords Adenosine - Receptor - Functional selectivity Biased signaling $\cdot$ Arrestin $\cdot$ Scaffold protein

$\begin{array}{ll}\text { Abbreviations } \\ \text { 2A3BT } & \text { 4-Substituted 2-amino-3-benzoylthiophene } \\ \text { 7TMR } & \text { Seven transmembrane receptor } \\ \mathrm{A}_{1} \mathrm{R} & \text { Adenosine receptor } \mathrm{A}_{1} \\ \mathrm{~A}_{2 \mathrm{~A}} \mathrm{R} & \text { Adenosine receptor } \mathrm{A}_{2 \mathrm{~A}} \\ \mathrm{~A}_{2 \mathrm{~B}} \mathrm{R} & \text { Adenosine receptor } \mathrm{A}_{2 \mathrm{~B}} \\ \mathrm{~A}_{3} \mathrm{R} & \text { Adenosine receptor } \mathrm{A}_{3} \\ \mathrm{AC} & \text { Adenylate cyclase } \\ \mathrm{ADA} & \text { Adenosine deaminase } \\ \mathrm{ARF} & \text { ADP-ribosylation factor } \\ \text { ARNO } & \text { ADP-ribosylation factor-nucleotide site opener } \\ \text { cAMP } & \text { Cyclic adenosine monophosphate } \\ \text { CHO } & \text { Chinese hamster ovary } \\ \mathrm{D}_{2} \mathrm{R} & \text { Dopamine } \mathrm{D}_{2} \text { receptor } \\ \text { DCC } & \text { Deleted-in-colorectal-cancer } \\ \text { DDT } & \text { Syrian hamster ductus deferens smooth muscle } \\ \text { MF-2 } & \text { tumor } \\ \text { ERK } & \text { Extracellular-regulated kinase } \\ \text { FRTL-5 } & \text { Fisher rat thyroid cell } \\ \text { cell } & \\ \text { GPCR } & \text { G protein-coupled receptor } \\ \text { GRK } & \text { G protein-coupled receptor kinase } \\ \text { HEK293 } & \text { Human embryonic kidney 293 } \\ \text { HSC } & \text { Hepatic stellate cells } \\ \text { Hsc73 } & \text { Heat shock cognate protein } 73 \\ \text { JNK } & \text { c-Jun N-terminal kinase } \\ \text { MAPK } & \text { Mitogen-activated protein kinase } \\ \text { NAM } & \text { Negative allosteric modulator } \\ \text { NECAB2 } & \text { Neuronal Ca }{ }^{2+} \text {-binding protein } 2 \\ \text { NF- } \mathrm{B} B & \text { Nuclear factor } \kappa \mathrm{B} \\ \text { NHERF } & \text { Na } / \mathrm{H}^{+} \text {exchanger regulatory factor } \\ \text { NMDA } & \text { N-methyl-D-aspartate } \\ & \end{array}$




$\begin{aligned} \text { PAM } & \text { Positive allosteric modulator } \\ \text { PC-12 } & \text { Rat adrenal pheochromocytoma-12 cell } \\ \text { cell } & \\ \text { PDZ } & \begin{array}{l}\text { Postsynaptic density protein 95/discs-large/ } \\ \text { Zo-1 protein }\end{array} \\ \text { PI3K } & \text { Phosphatidylinositol-3-kinase } \\ \text { PKA } & \text { Protein kinase A } \\ \text { PKC } & \text { Protein kinase C } \\ \text { PLC } & \text { Phospholipase C } \\ \text { PMN } & \text { Polymorphonuclear neutrophil } \\ \text { PTX } & \text { Pertussis toxin } \\ \text { TRAX } & \text { Translin-associated protein X } \\ \text { USP4 } & \text { Ubiquitin-specific protease } 4\end{aligned}$

See Fig. 1 for abbreviations of ligands.

\section{Introduction}

G protein-coupled receptors (GPCRs) are the most important class of drug-targetable cell surface proteins [1]. These receptors couple to several classes of heterotrimeric $G$ proteins consisting of $\mathrm{G} \alpha, \mathrm{G} \beta$, and $\mathrm{G} \gamma$ subunits that are activated upon receptor stimulation. Subsequently, the heterotrimeric $G$ protein dissociates into $G \alpha$ and $G \beta \gamma$ subunits, which on their turn activate intracellular targets. There are at least four families of $\mathrm{G}$ proteins namely $\mathrm{G} \alpha_{\mathrm{i}}$, $\mathrm{G} \alpha_{\mathrm{s}}, \mathrm{G} \alpha_{\mathrm{q}}$, and $\mathrm{G} \alpha_{12 / 13}$ that accommodate a variety of combinations between the 16 different $\mathrm{G} \alpha, 5 \mathrm{G} \beta$, and 14 $\mathrm{G} \gamma$ subunits [2]. $\mathrm{G} \alpha_{\mathrm{s}}$ and $\mathrm{G} \alpha_{\mathrm{i}}$ proteins activate or inactivate adenylate cyclase (AC), respectively, resulting in an increase or reduction of intracellular cyclic adenosine monophosphate (cAMP) concentrations. $\mathrm{G} \alpha_{\mathrm{q}}$ proteins activate phospholipase C (PLC) isoforms, resulting in for instance formation of inositol phosphates and a raise in intracellular $\mathrm{Ca}^{2+}$ concentration. Activation of $\mathrm{G} \alpha_{12 / 13}$ proteins is associated with changes of the cytoskeleton. The $G \beta \gamma$ subunits activate a broad variety of signal transduction pathways upon their release, such as PLC, $\mathrm{AC}$, protein kinase $\mathrm{D}$, c-Jun $\mathrm{N}$-terminal kinase (JNK), the non-receptor tyrosine kinase $\mathrm{Src}$ and phosphatidylinositol3-kinase (PI3K) and ion channels [2].

GPCRs consist of seven membrane-spanning $\alpha$-helices and are more and more often referred to as seven transmembrane receptors (7TMRs). This is not merely because of their membrane topology, but to account for the observation that these receptors can activate a variety of other proteins besides $G$ proteins. The best studied $G$ protein-independent signal transduction pathway activated by 7 TMRs is the one mediated by $\beta$-arrestins. Upon activation, 7TMRs are phosphorylated at their intracellular domains by GPCR kinases (GRKs), followed by recruitment and binding of $\beta$-arrestin-1 (also named arrestin-2), $\beta$-arrestin-2 (also named arrestin-3), or the visual arrestins1 and -4 [3-5].

Binding of $\beta$-arrestin functions as an off-switch for the receptor by preventing interaction with $G$ proteins and mediates internalization of the receptor. Besides their role in receptor desensitization and internalization, $\beta$-arrestins can function as adapter or scaffold proteins that mediate $G$ protein-independent activation of, e.g., mitogen-activated protein kinases (MAPKs) such as extracellular signalregulated kinases 1 and 2 (ERK1/2), Src, JNK, PI3K, or the transcription factor NF-KB [6, 7].The MAPKs ERK1/2 are two signaling proteins where $G$ protein-dependent and $\beta$-arrestin-mediated pathways can converge. Activation of ERK $1 / 2$ by 7 TMRs occurs via a variety of pathways and is often dependent on the cellular background in which such a response is measured. G protein-dependent ERK1/2 activation is spatially and temporally distinct from $\beta$-arrestinmediated $G$ protein-independent phosphorylation $[6,8]$. ERK1/2 activation via $G$ proteins often is rapid and transient, while $\beta$-arrestin-mediated ERK1/2 phosphorylation is delayed and sustained. Furthermore, ERK1/2 activated by $\beta$-arrestins has been reported to remain cytosolic, while ERK1/2 activated through G proteins is localized in the nucleus in addition to the cytosol [8].

7TMRs can be divided in two classes dependent on their interaction with $\beta$-arrestins: The first class binds $\beta$-arrestin- 2 with higher affinity than $\beta$-arrestin- 1 , while the second class of receptors binds both $\beta$-arrestins with equal affinity and additionally binds visual arrestins [4]. While $\beta$-arrestin- 1 and visual arrestin are found in both the cytoplasm and nucleus in the absence of an agonist in transfected human embryonic kidney 293 (HEK293) cells, localization of $\beta$-arrestin-2 is restricted to the cytoplasm [4]. Specific serine residues in the C-terminal tails of 7TMRs were shown to determine specificity for either $\beta$-arrestin-1 or $\beta$-arrestin- 2 . The complexes of receptors of the first class with $\beta$-arrestins were described to be relatively unstable and to readily dissociate at or near the plasma membrane, while $\beta$-arrestins bound to receptors of the second class were found to be more stable and to internalize together into endocytic vesicles [4]. In addition, $\beta$-arrestin- 1 and -2 were found to play different roles in internalization but not desensitization or downregulation of 7TMRs [5].

It is likely that $\beta$-arrestin- 1 and $\beta$-arrestin- 2 fulfill distinct and non-redundant functions in the cell, based on these differences and their different tissue expression. On the other hand, mouse knockout models of either $\beta$-arrestin- 1 or $\beta$-arrestin-2 show no gross phenotypes [3], while double knockout mice die at birth [9]. This indicates that absence of a $\beta$-arrestin isoform can be compensated for by the other isoform, pointing to at least a certain level of redundancy between the two proteins. Current knowledge from mouse knockout models suggests that $\beta$-arrestin- 2 plays a more 
important role in $\mathrm{G}$ protein-independent signaling than $\beta$-arrestin-1 [3].

\section{Functional selectivity}

Many 7TMRs show promiscuous coupling to $G$ proteins. When a receptor activates more than one class of $G$ proteins, distinct conformations of the receptor may favor coupling of one class of $\mathrm{G}$ proteins over another. Similarly, when a 7TMR activates a $G$ protein-independent $\beta$-arrestinmediated pathway in addition to $G$ proteins, one pathway may be preferred over the other, depending on the conformational state of the receptor. Moreover, ligands that bind the receptor may induce or stabilize receptor conformations that selectively couple to a certain pathway, while leaving the other pathway unaffected. These events are called functional selectivity or biased signaling. The principles of functional selectivity have been the subject of excellent and extensive reviews $[10,11]$.

Functional selectivity also implies that the concept of ligand efficacy is very assay dependent, since a full agonist for a certain pathway may be an antagonist, partial agonist or inverse agonist for another pathway mediated by the same receptor. Partial agonism and functional selectivity are two separate phenomena that can produce overlapping responses. It should therefore always be verified that apparent functional selectivity between agonists is not merely caused by variation in efficacy, since a high-efficacy agonist may activate more $\mathrm{G} \alpha$ subtypes than a low-efficacy agonist. For example, a full agonist for a given receptor may activate both $\mathrm{G} \alpha_{\mathrm{i}}$ and $\mathrm{G} \alpha_{\mathrm{q}}$ proteins, while a partial agonist may activate the $G \alpha_{i}$ pathway but may not be potent enough to activate $G \alpha_{\mathrm{q}}$ proteins as well. In this case, the partial agonist appears to selectively activate the $\mathrm{G} \alpha_{i}$ pathway, but this originates from a general lack of efficacy at the receptor. Also differences in receptor density between tissues may cause changes in potency and efficacy of agonists. In a tissue expressing high amounts of receptors, a partial agonist can become a full agonist, a mechanism referred to as receptor reserve or spare receptors. Likewise, if the ligand acts as a partial agonist on the tissue with high expression levels of the receptor, it may not be potent enough to elicit a response in a tissue expressing less receptors. However, if agonist A is a full agonist at $\mathrm{G} \alpha_{\mathrm{i}}$ and a partial agonist at $\mathrm{G} \alpha_{\mathrm{q}}$, and agonist $\mathrm{B}$ reversely shows partial agonism at $\mathrm{G} \alpha_{\mathrm{i}}$ and full agonism for the $\mathrm{G} \alpha_{\mathrm{q}}$-mediated pathway, a truly biased signal is observed. Therefore, functional selectivity between agonists is only detected if the rank order of efficacy or potency of the agonists for two pathways is reversed.

The binding site of the natural ligand of a receptor is referred to as the orthosteric binding site. Many receptors are also capable of binding (synthetic) molecules or proteins at sites different from the orthosteric site. These sites are called allosteric binding sites, and the ligands are named allosteric ligands. Allosteric ligands may be agonists on their own right, or modulate the signaling of the orthosteric ligand, in which case they are called positive or negative allosteric modulators, PAMs and NAMs, respectively (for reviews on allosteric modulation of 7TMRs in general see references $[11,12]$ and for allosteric modulation of adenosine receptors in particular see references [13, 14]). Allosteric ligands induce or stabilize specific receptor conformations, thereby changing the active state of the receptor and/or the mode the orthosteric ligand interacts with the receptor. This can be seen as fine-tuning of the receptor and its response. Even binding of a $G$ protein or other protein to the intracellular domains of a 7TMR can be seen as allosteric modulation, since this interaction stabilizes a certain (active) state of the receptor and influences binding of the orthosteric ligand. Since both orthosteric and allosteric ligands induce specific receptor conformations, interplay between both can be envisioned, so that an allosteric modulator can induce or enhance functional selectivity of an orthosteric ligand.

From a drug development point of view, the possibility to activate one pathway while leaving other pathways untouched offers unique possibilities with respect to selectivity and the prevention of side effects. For instance, the use of nicotinic acid to lower triglycerides and raise high-density lipoproteins is hampered by the adverse effects of cutaneous flushing, burning, and itching, since all these effects are mediated by the hydroxy-carboxylic acid receptor HCA2 (also named GPR109A). It seems however that cutaneous flushing is mediated by a $\beta$-arrestindependent pathway, while the anti-lipolytic effect is not [15]. Interestingly, a synthetic compound called MK-0354 lacks the vasodilatory effects responsible for skin flushing, but retains the anti-lipolytic signaling in vivo [16]. Indeed, MK-0354 was found to activate $G$ protein-dependent pathways, but not $\beta$-arrestin signaling $[15,16]$, indicating that it is possible to separate desired and unwanted effects using functionally selective drugs. This is only one example out of many: several other receptors for which a bias between $G$ protein-dependent and $\beta$-arrestin signaling pathways has been described, such as the $\beta_{1}$-and $\beta_{2^{-}}$ adrenergic receptors, the $\mu$-opioid receptor, the dopamine $\mathrm{D}_{2}$ receptor $\left(\mathrm{D}_{2} \mathrm{R}\right)$, serotonin receptors $5-\mathrm{HT}_{2 \mathrm{~A}}$ and $5-\mathrm{HT}_{2 \mathrm{C}}$, the angiotensin $\mathrm{AT}_{1 \mathrm{~A}}$ receptor, the chemokine CXCR4 receptor and the parathyroid hormone type 1 receptor have been recently reviewed [6].

Members of the JNK MAPK family have been shown to be important mediators of biased signaling events at opioid receptors [17]. It has been known for some time that a class of $\mu$-opioid ligands, including morphine, does not induce robust phosphorylation and internalization of the receptor, in contrast to other ligands such as endogenous enkephalins. Ligand-directed JNK activation was found to block G 
protein-coupling to $\mathrm{K}$-and $\mu$-opioid receptors and to be involved in long-term inactivation of the $\mathrm{K}$-opioid receptor as well as acute analgesic tolerance of the $\mu$-opioid receptor [17]. The mechanism leading to ligand-directed JNK activation is presently unknown but may involve $\beta$-arrestins. Nevertheless, JNK could represent a novel mediator of functionally selective responses for GPCRs in general.

Most research regarding functional selectivity has focused on selective activation of different classes of $G$ proteins, or biased activation of $\beta$-arrestins versus $G$ proteins. However, besides $\beta$-arrestins, 7TMRs interact with a variety of other intracellular scaffold proteins. Scaffold proteins can link the 7TMR to one or more other effectors, thereby facilitating efficient signal transduction by bringing all partners together in the same signaling complex. Scaffold proteins for instance can physically interact with proteins such as ERK1/2, Src, JNK, PLC, protein kinase A (PKA), ADP-ribosylation factornucleotide site opener (ARNO) and actin (see reference [7] for a review). Src, which is important in several signaling cascades leading to ERK1/2 phosphorylation, has even been shown to be directly activated by the $\beta_{2}$-adrenergic receptor [18]. Theoretically, scaffold proteins can stabilize receptor conformations that lead to functional selectivity. In practice, however, it will often be difficult to experimentally separate scaffolding functions from the allosteric effects induced by scaffold proteins [7].

Many scaffold proteins contain one or more PDZ (postsynaptic density protein 95/Discs-large/Zo-1 protein) motifs that interact with the distal part of the carboxyl terminus of 7TMRs. While phosphorylation of 7TMRs by GRKs often leads to recruitment of $\beta$-arrestins, phoshorylation of serine or threonine residues in a PDZ domain can prevent the association of a receptor with a scaffold protein [7]. Phosphorylation of 7TMRs by specific GRKs appears to be crucial for some biased responses, such as those elicited by the endogenously expressed chemokines CCL19 and CCL21 upon binding to the chemokine receptor CCR7. Although both ligands have comparable binding affinities and activate $\mathrm{G}$ protein-dependent pathways with equal potency, CCL19 but not CCL21 induced robust phosphorylation, $\beta$-arrestin-2 recruitment, and CCR7 desensitization [19]. In addition, CCL19-mediated ERK1/2 activation was partially mediated by $\beta$-arrestin-2. On the other hand, ERK1/2 activation was found to be completely dependent on $\mathrm{G} \alpha_{\mathrm{i}}$ activation. This suggests that CCL19-induced $\beta$-arrestin recruitment is triggered by phosphorylation of CCR7 by GRKs, which are activated in a $\mathrm{G} \alpha_{\mathrm{i}}$-dependent manner. Indeed, it was found that activation by CCL19 or CCL21 leads to differential GRK specificity for CCR7 [20]. In this study, CCL19 induced robust phosphorylation of CCR7 and recruitment of $\beta$-arrestin- 2 catalyzed by both GRK3 and GRK6, whereas CCL21 mediated phosphorylation and recruitment of $\beta$-arrestin- 2 was less pronounced and in- volved only GRK6. However, solely CCR7 phosphorylation and $\beta$-arrestin- 2 recruitment by CCL19 resulted in trafficking of CCR7 to endocytic vesicles and receptor desensitization. Both chemokines stimulated ERK1/2 involving GRK6 but not GRK3. Interestingly, GRK6 but not GRK3 is also important for $\beta$-arrestin-mediated ERK activation by $\beta_{2}$-adrenergic receptors, indicating that this may be a common mechanism [8]. It has been suggested that GRKspecific phosphorylation patterns of the receptor may be interpreted as a "barcode" that instructs adapter proteins such as $\beta$-arrestins which conformation to adapt, and therefore which scaffolding functions to perform [20]. Such a GRKinduced barcode would also confer specificity to the many possible interactions with the wide range of scaffold proteins that have been described for 7TMRs.

\section{Adenosine receptors}

Four 7TMRs for the endogenous molecule adenosine $\mathbf{1}$ have been described, named adenosine receptor $A_{1}\left(A_{1} R\right)$, adenosine receptor $A_{2 A}\left(A_{2 A} R\right)$, adenosine receptor $A_{2 B}$ $\left(A_{2 B} R\right)$, and adenosine receptor $A_{3}\left(A_{3} R\right.$; see Fig. 1 for structures of the ligands mentioned in this review) [21]. The best-known antagonist for $A_{1} R$ and $A_{2} R$ subtypes is caffeine, the active ingredient of coffee and tea. The adenosine $A_{1} R$ and $A_{2 A} R$ are highly expressed in the brain, where adenosine is involved in sleep/wakefulness and modulation of neurotransmitter responses $[21,22] . A_{1} R s$ interact with various neurotransmitter systems such as dopamine $\mathrm{D}_{1}$ and $N$-methyl-D-aspartate (NMDA) receptors, while $A_{2 A} R$ and $D_{2} R$-mediated signaling are closely linked. In the periphery, $A_{1} R s$ are expressed in adipose tissue and the atria of the heart where they are involved in for instance inhibition of lipolysis and bradycardia. In addition to the brain, $A_{2 A} R s$ are highly expressed on leukocytes and platelets. $\mathrm{A}_{2 \mathrm{~B}} \mathrm{Rs}$ are ubiquitously expressed at low levels and found in higher levels in the intestine and bladder [21,

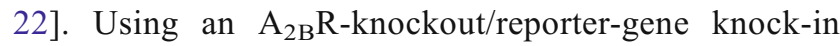
mouse model, it was shown that the primary site of $A_{2 B} R$ expression is the vasculature [23]. In addition to the vasculature, $\mathrm{A}_{2 \mathrm{~B}} \mathrm{R}$-gene promoter activity was high in macrophages [23]. The $A_{3} R$ is found in lung, liver, and other peripheral tissues, the brain, as well as on eosinophils and mast cells $[21,24]$.

Adenosine is present in all cells and extracellular fluids. During episodes of oxidative stress, ischemia and hypoxia the levels of adenosine increase, and activation of adenosine receptors is thought to play a protective role. Due to the broad expression of adenosine receptor subtypes, and the omnipresence of the endogenous agonist adenosine, selectivity of synthetic therapeutic adenosine ligands is very important. Such selectivity may sometimes be reached with 
Fig. 1 Adenosine

receptor ligands. The structures of ligands that are mentioned in the text are shown. The ligands are indicated in the text with a bold number when they are mentioned for the first time. At moments when structural information can contribute to the discussion, the ligands are indicated in the text with a bold number as well. Abbreviations: 2CdA 2-chloro-2'-

deoxyadenosine, 3'dA 3'deoxyadenosine, $C A D O 2-$ chloro-adenosine, CCPA 2chloro- $\mathrm{N}^{6}$-cyclopentyladenosine, CHA $\mathrm{N}^{6}$-cyclohexyladenosine, Cl-IB-MECA 2-chloro-N ${ }^{6}$ (3-iodobenzyl)-5'-Nmethylcarboxamidoadenosine, CPA $\mathrm{N}^{6}$-cyclopentyladenosine, $C P e C A$ 5'-N-cyclopentylcarboxamidoadenosine, DBXRM 1,3-dibutylxanthine-7-riboside5 '-N-methylcarboxamide, $D P C P X$ 8-cyclopentyl-1,3dipropylxanthine, DPMA $\mathrm{N}^{6}$ [2-(3,5-Dimethoxyphenyl)-2(2-methylphenyl)-ethyl] adenosine, IB-MECA $\mathrm{N}^{6}$ (3-iodobenzyl)-5'-Nmethylcarboxamidoadenosine, MECA 5'-N-methylcarboxamidoadenosine, NECA 5'-Nethylcarboxamidoadenosine, $R$-PIA N ${ }^{6}$-(1-methyl-2phenylethyl)adenosine<smiles>Nc1ncnc2c1ncn2[C]1O[C@@H](CO)[C@@H](O)[C@H]1O</smiles><smiles>Nc1ncnc2c1ncn2[C@@H]1O[C@H](CO)C[C@H]1O</smiles><smiles>Nc1nc(Cl)nc2c1ncn2C1CC(O)C(CO)O1</smiles><smiles>Nc1nc(Cl)nc2c1ncn2C1OC(CO)C(O)C1O</smiles><smiles>O=C(O)C1C(CO)O[C@@H](n2cnc3c(NC4CCCC4)ncnc32)C1O</smiles><smiles>[R7][R17]=NC=[W]</smiles><smiles>Nc1ncnc2c1ncn2[C@@H]1O[C@H](C(=O)NC2CCCC2)[C@H](O)[C@H]1O</smiles><smiles>[R]c1csc(N)c1C(=O)c1ccccc1</smiles>

$10 \mathrm{R}=3$-trifluoromethylphenyl $11 \mathrm{R}=3$,5-di-trifluoromethylphenyl<smiles>Nc1sc2c(c1C(=O)c1ccc(Cl)cc1)CCCC2</smiles><smiles>CC(C)(C)O[R6](=O)(=O)c1ccc(C(=O)c2c(-c3cccc(C(F)(F)F)c3)csc2N)cc1</smiles><smiles>CC(C)(C)C(C)(C)C</smiles><smiles>[Y]C([Pb])[R6]#P</smiles>

receptor subtype-specific compounds (see references [14, 25] for an overview of adenosine receptor ligands), but becomes problematic if the same receptor mediates different physiological processes. However, if different processes downstream of the same receptor are involved in a pathological condition, biased compounds would have the potential to selectively activate the therapeutically relevant pathway without affecting other signal transduction routes. Moreover, since an antagonist for a $\mathrm{G}$ protein-mediated response can still be an agonist for $\beta$-arrestin-mediated signaling, it is important to know if a drug shows functional selectivity in order to predict and prevent adverse effects.

Adenosine receptors are tightly regulated in terms of desensitization and internalization, mediated by GRKs and $\beta$-arrestins (reviewed in [24]). It is therefore not improbable that biased adenosine receptor ligands exist, which selectively activate $\beta$-arrestin-mediated signal transduction pathways. Adenosine receptors have been 
Fig. 1 (continued)<smiles>CCNC(=O)C1OC(n2cnc3c(N)nc(NCCc4ccc(CCC(=O)O)cc4)nc32)C(O)C1O</smiles><smiles>CCCn1c(=O)[nH]c2nc(-c3ccc(S(=O)(=O)O)cc3)[nH]c2c1=O</smiles>

19 PSB1115<smiles>CCOC1C(C(=O)NC)OC(n2cnc3c(N)ncnc32)C1O</smiles><smiles>[R]c1nc(NCc2cccc(I)c2)c2ncn(C3OC(C(=O)NC)C(O)C3O)c2n1</smiles><smiles>CCCOC(=O)c1c(-c2ccccc2)nc(CC)c(C(=O)SCC)c1CCC</smiles><smiles>[R16]c1ccc(-n2nc3c(=O)[nH]c4ccccc4n3c2=O)cc1</smiles><smiles></smiles>

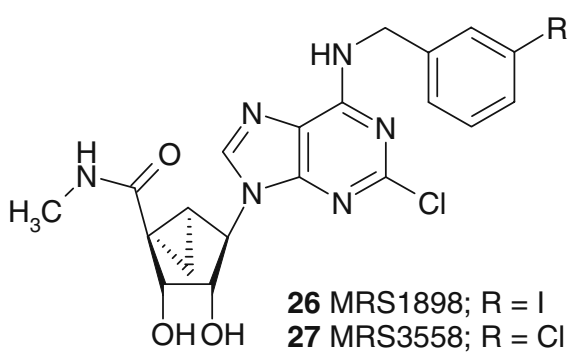<smiles>CCOC(=O)C1=C(C)NC(c2ccccc2)=C(C(=O)OCc2ccccc2)C1C#Cc1ccccc1</smiles>

reported to activate ERK1/2 in a variety of cell types, mediated by different downstream signaling components $[26$, 27]. Since both $G$ protein-dependent and -independent pathways often come together at the level of ERK1/2, some special attention to this MAPK will be dedicated in the paragraphs below describing the individual adenosine receptors.
Dimerization and oligomerization of 7TMRs can also be seen as allosteric modulation of the receptor and often results in modified binding and signaling properties compared to the monomeric receptor. Homo- and heterodimerization of adenosine receptors have recently been reviewed $[14,28]$ and a complete overview would be beyond the scope of the current review. 
Fig. 1 (continued)<smiles>COC(=O)C1=C2C=CN(C)C=C2c2nc(-c3ccccc3)nn2C1</smiles><smiles>OC1CSC(n2cnc3c(NCc4cccc(I)c4)nc(Cl)nc32)C1O</smiles><smiles>COc1cc(OC)cc(C(CNc2ncnc3c2ncn3C2OC(CO)C(O)C2O)c2ccccc2C)c1</smiles>
$\mathrm{HO}$

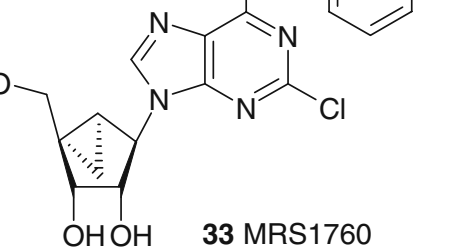<smiles>[R15]S(=O)(=O)c1cccc(CNc2nc(Cl)nc3c2ncn3C2OC(CO)C(O)C2O)c1</smiles><smiles>CCCCn1c(=O)c2c(ncn2C2OC(C(=O)NC)C(O)C2O)n(CCCC)c1=O</smiles>

\section{$A_{1}$ adenosine receptors}

$\mathrm{A}_{1}$ Rs couple to $\mathrm{G} \alpha_{\mathrm{i}(1-3)}$ proteins and $\mathrm{G} \alpha_{\mathrm{o}}$, and their main effects are thought to be through the inhibition of intracellular cAMP levels [29]. In addition, release of $\beta \gamma$-subunits from pertussis toxin (PTX)-sensitive $\mathrm{G} \alpha_{\mathrm{i}}$ proteins can result in the activation of PLC isoforms, followed by formation of inositol phosphates and diacylglycerol, and release of $\mathrm{Ca}^{2+}$ from intracellular stores [30]. The $\mathrm{A}_{1} \mathrm{R}$ activates ERK1/2 in Chinese Hamster Ovary $(\mathrm{CHO})$ cells as well as in a variety of other cell types [26, 27].

Functional selectivity of $A_{1}$ adenosine receptors

Besides the prototypical coupling of $A_{1} R$ to $G \alpha_{i}$ proteins, activation of $\mathrm{G} \alpha_{\mathrm{q}}$ and $\mathrm{G} \alpha_{\mathrm{s}}$ proteins [31] as well as promiscuous $\mathrm{G} \alpha_{16}$ proteins [32] has been reported (Fig. 2). The non-selective agonist NECA 8 and the $A_{1}$ R-selective agonists CPA 5 and R-PIA 7 were tested for their ability to stimulate $\mathrm{G} \alpha_{\mathrm{s}}$ and $\mathrm{G} \alpha_{\mathrm{q}}$ proteins after inactivation of $\mathrm{G} \alpha_{\mathrm{i}}$ proteins with PTX [31]. The experiments were performed

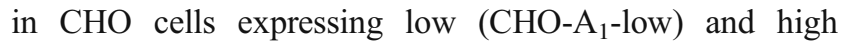
(CHO- $\mathrm{A}_{1}$-high) amounts of the $\mathrm{A}_{1} \mathrm{R}$. In PTX-treated CHO$\mathrm{A}_{1}$-low cells, NECA enhanced forskolin-induced cAMP accumulation, while CPA and R-PIA were unable to activate $\mathrm{G} \alpha_{\mathrm{s}}$ proteins. In the cells with high $\mathrm{A}_{1} \mathrm{R}$ expression levels all three agonists induced cAMP formation, indicating that NECA has a higher intrinsic efficacy for the $G \alpha_{\mathrm{s}}$ pathway than CPA and R-PIA. Indeed, in the $\mathrm{CHO}-\mathrm{A}_{1}$-high cells NECA was the most efficacious agonist in stimulating $\mathrm{G} \alpha_{\mathrm{s}}$ mediated cAMP accumulation compared to the other agonists, although it had the lowest potency. Similar to stimulation of $\mathrm{G} \alpha$ s proteins, NECA showed higher efficacy than CPA and R-PIA for PTX-insensitive $\mathrm{G} \alpha_{\mathrm{q}}$-mediated inositol phosphates formation, again while having lower potency. The efficacies of the agonists for the traditional $\mathrm{G} \alpha_{\mathrm{i}}$-mediated pathway were similar, and potencies found for $\mathrm{G} \alpha_{\mathrm{i}}$-activation were approximately 200 - to 1,200-fold higher than for $\mathrm{G} \alpha_{\mathrm{s}}$-mediated signal transduction and 1,700- to 20,000-fold higher than for $\mathrm{G} \alpha_{\mathrm{q}}$-mediated inositol phos- 


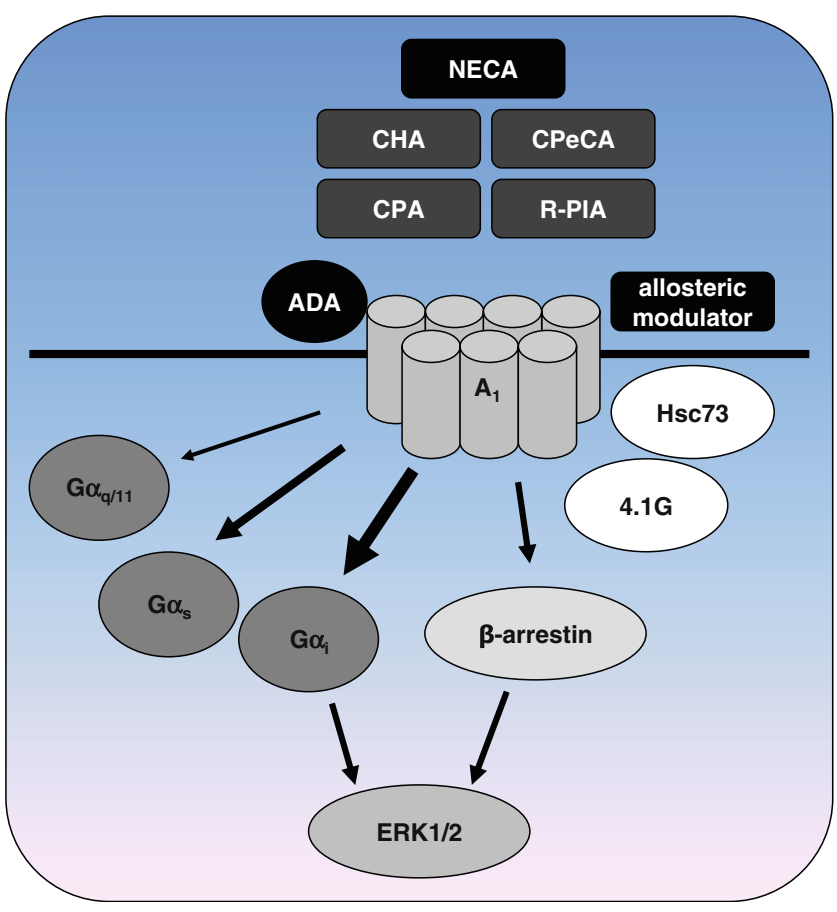

Fig. 2 Functional selectivity of the adenosine $A_{1}$ receptor. The $\mathrm{A}_{1} \mathrm{R}$ can activate $G \alpha_{s}$ and $G \alpha_{q / 11}$ proteins besides the classical $G \alpha_{i}$ pathway. The non-selective agonist $N E C A$ has higher intrinsic activity for these alternative pathways than $\mathrm{A}_{1} \mathrm{R}$-selective agonists. The intrinsic activities of $\mathrm{A}_{1} \mathrm{R}$-selective agonists such as $C H A, C P A$, and $C P e C A$ for the alternative $G$ proteins differ amongst each other as well. Allosteric modulators such as 2A3BT-class PAMs can bias signaling of orthosteric ligands. The endogenous enzyme $A D A$ appears to function as a natural extracellular allosteric modulator of $\mathrm{A}_{1} \mathrm{Rs}$, possibly in close cooperation with the intracellular scaffold protein $H s c 73$. Signaling through $\mathrm{G}$ proteins and $\beta$-arrestins converges at the level of ERK1/2 activation. Interaction with scaffold proteins like $4.1 G$ protein may favor functional selectivity by stabilizing distinct receptor conformations. See references in the text for more detailed information

phates accumulation. Although the $A_{1} R$ is expressed at high levels in this model, likely forcing the receptor to couple to $\mathrm{G}$ proteins which may not be activated in a more physiological setting, it appeared that NECA has a higher intrinsic activity for $\mathrm{G} \alpha_{\mathrm{q}}$ and $\mathrm{G} \alpha_{\mathrm{s}}$ than CPA en R-PIA (Fig. 2). In a follow-up study, a series of NECA and CPA analogs was tested in order to elucidate the structure-activity relationship underlying this functional selectivity [33]. All tested compounds were full agonists in the $\mathrm{G} \alpha_{\mathrm{i}}$-mediated inhibition of cAMP. Interestingly, the NECA-analog CPeCA 9, bearing a cyclopentyl instead of an ethyl group at the 5'N-position of NECA, showed higher efficacy for the $G \alpha_{\text {s }}$ pathway than for the $G \alpha_{q}$ pathway. Binding of NECA to the $\mathrm{A}_{1} \mathrm{R}$ is crucially depending on threonine residue $\mathrm{T} 7.42$ (T277) in TM7, as mutation of this residue abolishes binding for NECA, but not for R-PIA (7TMR numbering according to reference [34]). R-PIA 7 has an intact ribose group and is less efficacious in activating $G \alpha_{q}$ and $G \alpha_{\mathrm{s}}$ than NECA 8. Therefore interaction of the $5^{\prime}$-N-substituents of NECA $\mathbf{8}$ and
CPeCA 9 with T7.42 may be involved in functional selectivity towards PTX-insensitive pathways.

The $\mathrm{A}_{1} \mathrm{R}$-selective CPA-analog CHA 6, which has a cyclohexyl instead of a cyclopentyl group at the $\mathrm{N}^{6}$ position of adenosine, was more efficacious than CPA 5 in activating $G \alpha_{\mathrm{s}}$ and $\mathrm{G} \alpha_{\mathrm{q}}$, indicating that substitution at this position may induce functional selectivity too. This hydrophobic $\mathrm{N}^{6}$-moiety has been suggested to interact with amino acids in the TM3 domain of the receptor such as L3.33 (L88) and to confer $\mathrm{A}_{1} \mathrm{R}$-selectivity to ligands [35]. Differential interaction of the $\mathrm{N}^{6}$-cyclopentyl or cyclohexyl group of CPA 5 and CHA 6 with L3.33 may therefore underlie the observed differences in efficacy by stabilizing different receptor conformations.

That PTX-insensitive pathways can be physiologically relevant is illustrated by the $A_{1} R$-mediated activation of the transcription factor NF- $\mathrm{kB}$ by CHA, through proteins of the promiscuous $\mathrm{G} \alpha_{16}$ class in the human lymphoblastoma Reh cell line [36]. $\mathrm{G} \alpha_{16}$ proteins are mainly expressed in hematopoietic cells and the agonist-dependent differences in efficacy between PTX-sensitive and PTX-insensitive responses described above raise the question if functionally selective compounds can be designed that specifically target these $\mathrm{G} \alpha_{16}$-mediated pathways.

A series of 4-substituted 2-amino-3-benzoylthiophenes (2A3BTs) was tested for their ability to act as allosteric enhancers of ERK1/2 activation by the orthosteric $A_{1} R$ selective ligand R-PIA [37]. Two compounds showed allosteric enhancement of R-PIA-induced ERK1/2 activation, as well as partial agonism in the absence of R-PIA. These compounds, with 3-trifluoromethylphenyl 10 [38] and 3,5di-trifluoromethylphenyl $\mathbf{1 1}$ substituents of the 4-position, were additionally tested in a $\left[{ }^{35} \mathrm{~S}\right] \mathrm{GTP} \gamma \mathrm{S}$ binding assay. Using an operational model of allosterism it was calculated that the 3-trifluoromethylphenyl substituted compound $\mathbf{1 0}$ showed a significant difference in positive cooperativity between enhancement of R-PIA-induced ERK1/2 activation and $\left[{ }^{35} \mathrm{~S}\right] \mathrm{GTP} \gamma \mathrm{S}$ binding. The authors suggested that this allosteric enhancer displays functional selectivity with respect to the amount of allosteric potentiation, depending on the pathway that is investigated.

The observation that the 2A3BT-class of allosteric enhancers may bias the signaling of the orthosteric ligand towards a certain signal transduction pathway was further investigated with another panel of allosteric modulators, i.e., T62 12, VCP520 13, and VCP333 14 [39]. All allosteric compounds acted as partial agonists for ERK1/2 activation and for inhibition of cAMP accumulation in the absence of the orthosteric agonist R-PIA in intact $\mathrm{CHO}$ cells, except for VCP333 which was almost devoid of ERK1/2 signaling. The compounds were inactive in an intracellular $\mathrm{Ca}^{2+}$ mobilization assay in the absence of $\mathrm{R}$ PIA. Surprisingly, while the potency of the orthosteric 
ligand R-PIA was about tenfold higher for ERK1/2 activation than for inhibition of cAMP, the opposite was true for the allosteric partial agonists that were more potent for the inhibition of cAMP than for ERK1/2 activation. This is a typical example of functional selectivity and indicates that the allosteric ligands bias $\mathrm{A}_{1} \mathrm{R}$ signaling towards different pathways than R-PIA, by stabilizing different receptor conformations compared to the orthosteric ligand. When tested in the presence of R-PIA, the allosteric compounds enhanced the potency of R-PIA-mediated signaling and in addition increased the efficacy for $\mathrm{Ca}^{2+}$ mobilization. Using the operational model of allosterism, it was calculated that the VCP520-mediated potentiation of R-PIA signaling in the $\mathrm{Ca}^{2+}$ mobilization assay was significantly greater than for ERK1/2 activation, again pointing towards functional selectivity. VCP520 13 differs only in one atom from the abovementioned 3-trifluoromethylphenyl substituted 2A3BT 10 [37] (i.e., a chloro vs. a hydrogen at the 4-position of the benzoyl group), suggesting that the 3-trifluoromethylphenyl substituent of the 2A3BT may be of importance for functional selectivity of 2A3BTs. The same laboratory also observed that the 2A3BT class of allosteric modulators has a receptorindependent effect as inhibitors of an intracellular component at the level of $\mathrm{G}$ proteins, when used at higher concentrations in membrane preparations but not in intact cells [39]. This finding indicates that care must be taken in the choice of assay used to determine the effects of 2A3BTs.

\section{$\beta$-arrestins}

In addition to coupling to $\mathrm{G}$ proteins, $\mathrm{A}_{1} \mathrm{Rs}$ can interact with several other proteins, raising the possibility to signal through $\mathrm{G}$ protein-independent pathways (Fig. 2). Interaction of GPCRs with $\beta$-arrestins is one of the best-described pathways through which ligands may demonstrate functional selectivity. Upon stimulation of the $A_{1} R$ with the $A_{1} R$ selective agonist R-PIA in CHO cells, $\beta$-arrestin-2 was redistributed from the cytoplasm to punctuate spots located near the plasma membrane [40]. Surprisingly, no internalization of $A_{1} R$ was detected, and there was no significant overlap between the localization of $A_{1} R$ and $\beta$-arrestin-2. On the other hand, knock-down of $\beta$-arrestin-1 in Syrian hamster ductus deferens smooth muscle tumor (DDT ${ }_{1}$ MF-2) cells almost completely abrogated downregulation of the $A_{1} R$ upon 24-h stimulation with R-PIA [41]. Short-term stimulation of $\mathrm{DDT}_{1}$ MF-2 cells with R-PIA resulted in a rapid translocation of $\beta$-arrestin- 1 to the membrane. Stimulation of these cells with R-PIA also resulted in a rapid and transient ERK1/2 activation, which was abolished after knock-down of $\beta$-arrestin-1, indicating that $A_{1}$ can activate ERK1/2 via $\beta$ arrestin-1. This is in contrast with the observation that ERK1/ 2 activation by $\beta$-arrestin often results in a sustained second phase of ERK1/2 phosphorylation [6, 8]. Nevertheless, this $\beta$-arrestin-mediated activation of ERK1/2 is of particular interest since ERK1/2 activation may be important for the cardioprotective effect mediated by $\mathrm{A}_{1} \mathrm{Rs}$ during ischemia/ reperfusion [42-44]. Agonists for the $A_{1} R$ that show functional selectivity for the $\beta$-arrestin/ERK pathway may therefore be useful for cardioprotection, provided that $\beta$ arrestin-mediated ERK activation indeed is part of the mechanism of cardioprotection. This may not be the case, as ERK1/2 activation in rat cardiomyocytes was shown to be completely sensitive to treatment with PTX, and was suggested to involve $\beta \gamma$-subunits from $G_{i}$ proteins, genistein-sensitive Src tyrosine kinases, PKC, and PLC instead of $\beta$-arrestins [44].

Although $\mathrm{A}_{1} \mathrm{R}$-mediated ERK1/2 activation has been shown to be dependent on either $G$ proteins or $\beta$-arrestins, no biased ligands have been reported that favor one pathway over the other.

Internalization by adenosine $\mathrm{A}_{1}$ receptors antagonists

Ligand-induced internalization of GPCRs can occur independently of $G$ protein activation, for instance by stabilizing receptor conformations that promote $\beta$-arrestin recruitment and internalization. Both the agonist R-PIA and the $A_{1} R$ antagonist/inverse agonist DPCPX 15 induced internalization of $\mathrm{A}_{1} \mathrm{Rs}$ in rat $\mathrm{GH}_{4}$ pituitary cells [45]. In contrast, incubation of $\mathrm{DDT}_{1}$ MF-2 cells with R-PIA resulted in downregulation, while DPCPX induced upregulation of $\mathrm{A}_{1} \mathrm{Rs}$ [46]. The upregulation of $\mathrm{A}_{1} \mathrm{Rs}$ by the inverse agonist/antagonist DPCPX in $\mathrm{DDT}_{1} \mathrm{MF}-2$ cells can be explained by stabilization of the receptor and is more often observed for inverse agonists [47]. However, the observed downregulation by the inverse agonist/antagonist DPCPX in rat $\mathrm{GH}_{4}$ cells suggests a $\mathrm{G}$ protein-independent mechanism, indicating that DPCPX may display functional selectivity through for instance $\beta$-arrestin-mediated pathways.

Full agonists versus partial agonists

A different method of reaching tissue-selective effects of $A_{1} R$ agonists has been through the use of partial agonists instead of full agonists. Agonists of $\mathrm{A}_{1} \mathrm{Rs}$ may be useful in the treatment of non-insulin-dependent diabetes mellitus because of their anti-lipolytic effects. However, the expression of $\mathrm{A}_{1} \mathrm{Rs}$ in the body is widespread and selective anti-lipolytic action seems to be hard to obtain. More importantly, stimulation of $\mathrm{A}_{1} \mathrm{Rs}$ in the heart by full agonists can lead to adverse cardiovascular effects such as severe bradycardia and AV block. In order to be useful in the treatment of noninsulin-dependent diabetes mellitus, the cardiac side effects have to be separated from the anti-lipolytic properties. Interestingly, several 8-alkylamino-substituted analogs of the agonist CPA 5 showed less-pronounced decreases in 
heart rate and mean arterial pressure than CPA itself when tested in vivo in rats, acting as partial agonists on these responses [48]. When these CPA analogs were tested for their anti-lipolytic effects in vivo, it was found that they reduced lipolysis to levels which were almost comparable to the full agonist CPA, although they are partial agonists with respect to lowering the heart rate [49]. The selectivity between bradycardia and anti-lipolytic effect was dependent on differences in potency and intrinsic activity of the CPA analogs for the two effects. This intriguing finding was explained by the difference in receptor reserve between heart tissue and adipose tissue. Depending on the amount of receptors present in a tissue and their efficiency in coupling to a certain intracellular response, low-efficacy agonists can act as full agonists, partial agonists, or antagonists. Therefore, it is possible to develop anti-lipolytic effects without severe cardiovascular effects, making use of the fact that receptor reserve in adipose tissue is higher than in cardiac tissue [49]. Similarly, the negative effects of $A_{1} R$ agonists on the cardiovascular system hamper the development of $A_{1}$ agonists as potential antiarrhythmic drugs. It has been suggested that this problem can be overcome by the development of partial $A_{1} R$ agonists, which may moderately slow AV conduction time and control ventricular rate during periods of atrial tachycardias, without causing serious cardiovascular side effects. For instance, CVT-2759 16 was identified as a partial agonist compared to the full agonist CPA 5 for slowing AV nodal conduction in guinea pig isolated hearts, without causing AV block or severe slowing of atrial rate [50]. This effect is also attributed to the relatively low expression of $A_{1} R s$ in the heart, resulting in an absence of receptor reserve. Indeed, when tested in Fisher rat thyroid (FRTL-5) cells or rat epididymal adipocytes which have higher $A_{1} R$ expression, CVT-2759 acted as a full agonist [50]. These results indicate that partial $A_{1} R$ agonists may also be useful as antiarrhythmic drugs. The tissueselective effects of partial agonists described in this paragraph should not be mistaken for functional selectivity, as the observed selectivity solely relies on differences in receptor density between tissues.

Indications of functional selectivity at adenosine $A_{1}$ receptors

There are some additional indications that $\mathrm{A}_{1} \mathrm{Rs}$ have the potential to direct extracellular signals to specific pathways. For instance, overexpression of $G$ protein-coupled receptor kinase 2 (GRK2) inhibited G $\beta \gamma$-mediated ERK1/2 activation, but not $\mathrm{G} \alpha_{\mathrm{i}}$-mediated inhibition of cAMP in FRTL-5 cells [51]. Expression of GRK2- $\mathrm{K}^{220} \mathrm{R}$, a kinase-dead dominant negative mutant of GRK2, did not influence ERK1/2 activation or cAMP reduction, indicating that the regulation of ERK1/2 activity was not due to $\beta \gamma$-scavenging by GRK2. It was suggested that the differential regulation of ERK1/2 and cAMP is due to the ability of GRK2 to phosphorylate the $A_{1} R$ in a manner that affects $G \beta \gamma$-mediated signaling but not $\mathrm{G} \alpha_{\mathrm{i}}$-mediated signaling. Adenosine and CPA were used as agonists in this study, and it would be interesting to see if other ligands would be able to influence this GRK2-mediated bias in signaling.

Another example of an endogenous protein that can influence $A_{1} R$ signaling is the ectoenzyme adenosine deaminase (ADA) which breaks down adenosine into inosine (Fig. 2). This enzyme is often added to in vitro studies with adenosine receptors in order to prevent effects of endogenous adenosine. ADA interacts directly with the $\mathrm{A}_{1} \mathrm{R}$ in pig brain cortical membranes and $\mathrm{DDT}_{1} \mathrm{MF}-2$ cells and interestingly the interaction of ADA with an extracellular domain of the $A_{1} R$ is necessary to induce the $G$ protein-coupled highaffinity state of the receptor [52, 53]. Human ADA was shown to increase both agonist and antagonist binding on human brain striatal membranes, and to act as a positive allosteric modulator by increasing the potency of R-PIA more than tenfold in CHO cells [54]. While ADA increases binding of agonists and antagonists to the $\mathrm{A}_{1} \mathrm{R}$, it was shown to decrease binding of the pig $A_{1} R$ to the heat shock cognate protein Hsc73 [55]. Hsc73 by itself reduces binding of the agonist R-PIA and the $\mathrm{A}_{1} \mathrm{R}$-selective inverse agonist DPCPX and reduces activation of $G$ proteins through an interaction with the third intracellular loop of the $A_{1} R$ [55]. The Hsc73mediated reduction in binding of R-PIA and DPCPX could be reversed by addition of ADA. Since ADA binds to an extracellular domain [53] and Hsc73 to the third intracellular loop, it was suggested that binding of ADA affects the structure of the third intracellular loop, thereby inhibiting binding of $\mathrm{Hsc} 73$ [55]. If $\mathrm{Hsc} 73$ acts as an inhibitor of ligand binding to the $A_{1} R$, the release of Hsc73 upon incubation with ADA may explain the positive effects that ADA has on ligand affinity and potency. Both proteins appear to be involved in internalization processes of the receptor. ADA enhanced and accelerated R-PIA-induced phosphorylation of the $A_{1} R$ and increased the rate of desensitization and internalization [56]. In addition, ADA colocalizes with the $\mathrm{A}_{1} \mathrm{R}$ on the plasma membrane and in intracellular vesicles upon R-PIA-induced internalization. Hsc73 also colocalizes with the $\mathrm{A}_{1} \mathrm{R}$ on the plasma membrane, but upon internalization into intracellular vesicles, $\mathrm{Hsc} 73$ is only found together with the $\mathrm{A}_{1} \mathrm{R}$ in some of the $\mathrm{A}_{1} \mathrm{R}$-containing vesicles. The authors suggested that binding of ADA to the extracellular domain of the $A_{1} R$ may prevent association of Hsc73 during sequestering into intracellular vesicles, resulting in different $A_{1} R$ trafficking depending on the presence of ADA or Hsc73. Hsc73 is also involved in internalization of the chemokine receptor CXCR4, and knock-down of Hsc73 inhibits CXCR4-mediated chemotaxis without affecting ligand binding, indicating the potential regulation of signaling pathways by this heat shock protein [57]. It is unknown 
if ADA or Hsc73, which can be considered endogenous allosteric modulators, can bias signaling of orthosteric $A_{1} R$ agonists towards a preferred intracellular pathway, analogous to the synthetic allosteric modulators of the 2A3BT class described above.

Upon stimulation of the $\mathrm{A}_{1} \mathrm{R}$ with R-PIA in pig kidney epithelial LLC-PK cells, the $A_{1} R$ and ADA aggregate on the cell surface and translocate into intracellular compartments [58]. In these intracellular vesicles, the $A_{1} R$ was found to colocalize with caveolin and to interact with caveolin-1 through its C-terminal domain. Caveolins are an important component of caveolae, which are microdomains in the cell membrane that orchestrate signal transduction and receptor trafficking. Further interactions of the $\mathrm{A}_{1} \mathrm{R}$ with caveolins have been reported for caveolin-1 [59] and caveolin-3 [60]. Interaction of the $A_{1} R$ with proteins of the caveolin family implies localization of $A_{1} R s$ in these microdomains, where they can activate caveolae-specific pathways that may not be available in other subcellular compartments, for instance regulation of ATP-sensitive $\mathrm{K}^{+}$channels [60]. Surprisingly, $\mathrm{A}_{1}$ Rs have been shown to leave caveolae upon activation by agonists [61]. Caveolae contain members of the MAPK family as well, and besides interacting with the $A_{1} R$, caveolin-3 interacts directly with ERK2 but not ERK1 in rat cardiomyocytes [62]. The $A_{1} R$ agonist CCPA stimulated phosphorylation of both ERK1 and ERK2 in cytosolic fractions of these cells, whereas in caveolin-3 enriched fractions phosphorylation of ERK2 was reduced and phosphorylation of ERK1 was unchanged.

In a yeast two-hybrid screen an interaction of the third intracellular loop of the rat $A_{1} R$ with the cytoskeletal $4.1 \mathrm{G}$ protein was identified [63] (Fig. 2). Colocalization of $A_{1} R s$ and $4.1 \mathrm{G}$ was shown in the mouse cerebral cortex microglia as well [64]. Cotransfection of the rat $A_{1} R$ and $4.1 \mathrm{G}$ protein in HEK293 cells resulted in a remarkable loss of binding of the inverse agonist $\left[{ }^{3} \mathrm{H}\right]$-DPCPX, observed as a 40 -fold lower $B_{\max }$ and almost 60 -fold increase in $K_{\mathrm{d}}$ compared to cells expressing the $A_{1} R$ alone. The ability of the agonist CPA to inhibit forskolin-induced cAMP accumulation in $\mathrm{CHO}$ cells cotransfected with $4.1 \mathrm{G}$ protein was reduced by approximately $50 \%$, whereas mobilization of intracellular $\mathrm{Ca}^{2+}$ by CPA was completely abolished. This suggests that binding of $4.1 \mathrm{G}$ to the $\mathrm{A}_{1} \mathrm{R}$ affects calcium mobilization more than cAMP inhibition, and may indicate that the $4.1 \mathrm{G}$ protein induces functional selectivity for CPA. However, these differences may also arise from the type of assay or concentration of CPA that was used in the assays. Altogether, these findings demonstrate that the localization of $\mathrm{A}_{1} \mathrm{Rs}$ in subcellular compartments such as caveolae can contribute to activation of specific pathways (such as $\mathrm{K}^{+}$channels) and to differential regulation of ERK1/2. Scaffolding proteins such as caveolins or 4.1G may also stabilize conformations of the receptor that may be preferred by some ligands over other confirmations, thereby inducing functional selectivity. However, such ligands have yet to be identified.

\section{$\mathbf{A}_{2 \mathrm{~A}}$ adenosine receptors}

The $A_{2 A} R$ is coupled to $G \alpha_{s}$ and $G_{\text {olf }}$ proteins [65, 66], but has also been reported to interact with hematopoietic $\mathrm{G} \alpha_{15 / 16}$ proteins [67] (Fig. 3). Activation of ERK1/2 in CHO cells expressing the $\mathrm{A}_{2 \mathrm{~A}} \mathrm{R}$ is biphasic and less pronounced than activation mediated through the $G \alpha_{i}$-coupled $A_{1} R$ or $A_{3} R$ $[27,68]$. The mechanism of ERK1/2 activation by $A_{2 A} R s$ was compared between transfected HEK293 and CHO cells and appeared to be highly cell-type dependent $[26,69]$. In $\mathrm{CHO}$ cells, $\mathrm{A}_{2 \mathrm{~A}} \mathrm{R}$-mediated ERK1/2 activation was $\mathrm{G} \alpha_{\mathrm{s}}-$ dependent, while in HEK293 cells $\mathrm{G} \alpha_{\mathrm{s}^{-}}, \mathrm{G} \alpha_{\mathrm{i}^{-}}$, and PKCindependent ERK1/2 activation was observed that required p2 ${ }^{\text {ras }}[69,70]$. It was suggested that $A_{2 A}$ Rs may couple to $\mathrm{G} \alpha_{12 / 13}$ proteins in HEK293 cells, or activate ERK1/2 through $\mathrm{G}$ protein-independent pathways. ERK1/2 activation by the $\mathrm{A}_{2 \mathrm{~A}} \mathrm{R} / \mathrm{A}_{3} \mathrm{R}$-selective agonist CGS21680 17 in $\mathrm{CHO}$ cells was shown to be mediated via a $\mathrm{G} \alpha_{\mathrm{s}} / \mathrm{cAMP} / \mathrm{PKA} / \mathrm{Src}-$ like kinase dependent pathway [68]. Hepatic stellate cells (HSC) play an important role in the pathogenesis of hepatic

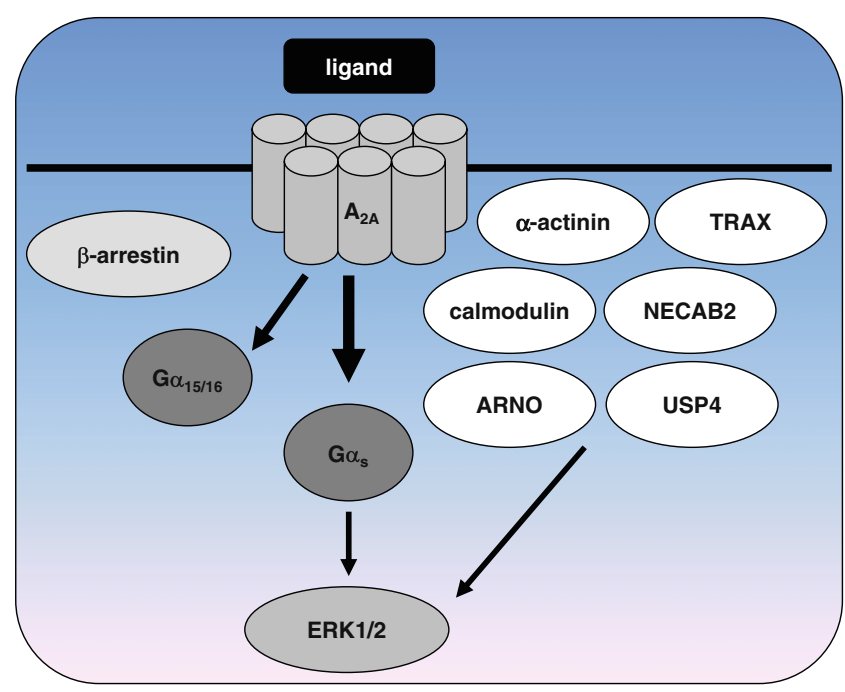

Fig. 3 Potential for functional selectivity of the adenosine $A_{2 A}$ receptor. Although no functionally selective ligands for the $\mathrm{A}_{2 \mathrm{~A}} \mathrm{R}$ have been identified to date, this adenosine receptor in particular bears potential for biased signaling. Its exceptionally long carboxyl terminus interacts with a variety of scaffold proteins such as $\beta$-arrestins, $\alpha$-actinin, ARNO, calmodulin, NECAB2, USP4, and TRAX. Besides the classical activation of $G \alpha_{s}$ proteins by $\mathrm{A}_{2 \mathrm{~A}} \mathrm{Rs}$, interaction with $G a_{15 / 16}$ proteins of the $\mathrm{G} \alpha_{\mathrm{q} /}$ ${ }_{11}$ family has been reported. Both $G$ protein-dependent and -independent pathways can lead to phosphorylation of ERK1/2 by $\mathrm{A}_{2 \mathrm{~A}} \mathrm{R}$. Several lines of research indicate that interaction with scaffold proteins tethers $\mathrm{A}_{2 \mathrm{~A}} \mathrm{Rs}$ to microdomains in the plasma membrane, where they may engage selective signal transduction pathways. See references in the text for more detailed information 
fibrosis and cirrhosis because they produce matrix proteins such as collagen after activation. Collagen type I expression by HSC upon stimulation of $\mathrm{A}_{2 \mathrm{~A}} \mathrm{R}$ with $\mathrm{CGS} 21680$ was shown to be regulated by a pathway involving PKA, Src, and ERK1/2, whereas collagen type III depended on activation of $\mathrm{p} 38$ MAPK but not PKA, Src, and ERK1/2 [71]. It is not known at which level the ERK $1 / 2$ and p38 pathways activated by the $A_{2 A} R$ start to diverge. If they diverge at the level of the $\mathrm{A}_{2 \mathrm{~A}} \mathrm{R}$ itself, it may be possible to selectively activate either the ERK1/2 or p38 with biased ligands in these cells.

In contrast to the other adenosine receptors, which have C-terminal tails of about 30-40 amino acids, the carboxyl terminus of the $\mathrm{A}_{2 \mathrm{~A}} \mathrm{R}$ consists of 122 amino acids. This long C-terminal tail offers the opportunity to interact with many intracellular proteins that may stabilize receptor conformations required for functional selectivity or mediate $G$ proteinindependent signaling. There is a rapidly expanding list of proteins that have been shown to interact with the C-terminus of the $\mathrm{A}_{2 \mathrm{~A}} \mathrm{R}$ including $\alpha$-actinin [72], ARNO/cytohesin-2 [73], the de-ubiquinating enzyme ubiquitin-specific protease 4 (USP4) [74], translin-associated protein X (TRAX) [75], neuronal $\mathrm{Ca}^{2+}$-binding protein 2 (NECAB2) [76], and calmodulin [77] (Fig. 3). In addition, a recent review about proteins that interact with the $\mathrm{A}_{2 \mathrm{~A}} \mathrm{R}$ C-terminus describes neuroendocrine-discs large homolog $3 /$ synapse-associated protein 102 (NE-DLG/SAP102), 14.3.3 protein- $\theta / \tau$ and astrin as candidate proteins [78]. Translocation of $\beta$-arrestin- 1 and $\beta$-arrestin-2 upon stimulation of transfected HEK293 cells with the agonist CGS21680 indicates that the $\mathrm{A}_{2 \mathrm{~A}} \mathrm{R}$ interacts with $\beta$-arrestins as well [72].

The importance of the C-terminus for the activation of distinct signal transduction pathways was shown using C-terminally truncated versions of the receptor [79]. Truncation of the $A_{2 A} R$ blunts constitutive cAMP formation in intact HEK293 cells, but leaves ERK1/2 activation unaffected. When using membranes instead of intact cells, no differences in constitutive $\mathrm{G}$ protein activation could be observed between WT and truncated receptors, suggesting an intracellular component that binds to the C-terminus in intact cells and stabilizes the signaling complex responsible for ERK1/2 activation [79]. Since binding of any of these adapter proteins may mediate biased signaling, they will be described in more detail in the following sections.

ARNO, $\alpha$-actinin, and calmodulin

A possible explanation for the $G$ protein-independent ERK1/2 activation described above is binding of ARNO, also named cytohesin-2, to the C-terminus of the $\mathrm{A}_{2 \mathrm{~A}} \mathrm{R}$ [73]. ARNO is a nucleotide exchange factor for the small $\mathrm{G}$ proteins of the ADP-ribosylation factor (ARF) family, i.e., ARNO catalyzes the replacement of GDP by GTP at these monomeric $G$ proteins. ARNO was picked up during a yeast two-hybrid screen and interacts with the membrane proximal part of the $\mathrm{C}$-tail of the $\mathrm{A}_{2 \mathrm{~A}} \mathrm{R}$ that is forming the intracellular helix 8. Expression of ARNO or a dominant negative form of ARNO had no effect on the expression levels of the $\mathrm{A}_{2 \mathrm{~A}} \mathrm{R}$, the affinity of the inverse agonist radioligand $\left[{ }^{3} \mathrm{H}\right]$-ZM241385 18 [80], G $\alpha_{\mathrm{s}}$-dependent accumulation of cAMP, or receptor desensitization in HEK293 cells [73]. Activation of ERK1/2 after 5-min stimulation with the selective $A_{2 A} R / A_{3} R$ agonist CGS21680 was also not affected. However, expression of the dominant negative mutant of ARNO inhibited sustained ERK1/2 activation upon longer stimulation times. These effects were likely mediated through interactions of ARNO with ARF6, since a dominant negative mutant of ARF6 also inhibited sustained ERK1/2 activation. Although ARNO-mediated signaling only explains the sustained ERK $1 / 2$ activation, and not the initial raise in ERK phosphorylation, it is a good example of $\mathrm{G}$ protein-independent signal transduction and suggests possibilities for agonists that selectively activate this pathway.

In the example above, expression of the dominant negative mutant of ARNO affected sustained ERK1/2 activation in HEK293 cells, but not $\mathrm{G} \alpha_{\mathrm{s}}$-mediated signaling. In contrast, depletion of cholesterol inhibits coupling of the $A_{2 A} R$ to $G \alpha_{s}$ in HEK293 cells, while leaving $\mathrm{G} \alpha_{\mathrm{s}}$-independent ERK1/2 activation unaffected [81]. Therefore it seems that cholesterol-rich membrane microdomains are required for the interaction of the $A_{2 A} R$ with $G \alpha_{s}$ proteins but not for the activation of ERK1/2. It is tempting to speculate that such a $\mathrm{G} \alpha_{\mathrm{s}^{-}}$and cholesterol-independent ERK1/2 activation is mediated by ARNO. A very remarkable feature of the $\mathrm{A}_{2 \mathrm{~A}} \mathrm{R}$ is its tight precoupling to the $\mathrm{G} \alpha_{\mathrm{s}}$ protein [82]. This phenomenon is referred to as restricted collision coupling, indicating that encounters between the agonist-occupied $\mathrm{A}_{2 \mathrm{~A}} \mathrm{R}$ and $\mathrm{G} \alpha_{\mathrm{s}}$ proteins do not occur at random at the cell membrane, but by keeping the interaction partners in close proximity in microdomains. These microdomains may for instance be cholesterol-rich lipid rafts, which would explain the diminished interaction of $A_{2 A} R$ and $G \alpha_{s}$ upon depletion of cholesterol [81]. Microdomains form an excellent platform for functionally selective ligands, since in microdomains receptors only encounter selected $G$ proteins that are present in these rafts such as $G \alpha_{\mathrm{s}}$, but not other proteins such as $G \alpha_{15 / 16}$ or ARNO, resulting in selective responses.

One of the proteins that may be necessary for the localization of $\mathrm{A}_{2 \mathrm{~A}} \mathrm{Rs}$ in microdomains is $\alpha$-actinin, by tethering the $\mathrm{A}_{2 \mathrm{~A}} \mathrm{R}$ to the cytoskeleton [78]. The cytoskeletal protein $\alpha$-actinin is involved in $\mathrm{F}$-actin crosslinking and was shown to interact with the $\mathrm{C}$-terminal end of $\mathrm{A}_{2 \mathrm{~A}} \mathrm{Rs}$ [72]. In addition, treatment of HEK293 cells expressing the $A_{2 A} R$ with cytochalasin $\mathrm{D}$, which causes disruption of actin filaments and inhibition of actin polymerization, inhibits 
internalization of the $\mathrm{A}_{2 \mathrm{~A}} \mathrm{R}$ indicating a functional relationship between $A_{2 A}$ Rs and the underneath actin structure [72]. That the interaction of $\mathrm{A}_{2 \mathrm{~A}} \mathrm{Rs}$ with the cytoskeleton via $\alpha$-actinin may be physiologically important was shown in rat neostriatal neurons, which express the $\mathrm{A}_{2 \mathrm{~A}} \mathrm{R}$ endogenously [83]. Activation of $\mathrm{A}_{2 \mathrm{~A}} \mathrm{Rs}$ by CGS21680 inhibits an NMDAinduced current in these neurons. The $\mathrm{A}_{2 \mathrm{~A}} \mathrm{R}$-mediated inhibition of this current was abolished upon treatment with cytochalasin $\mathrm{B}$ that enhances actin depolymerization, indicating an important interaction between the $\mathrm{A}_{2 \mathrm{~A}} \mathrm{R}$ and the cytoskeleton which may be mediated by $\alpha$-actinin. In addition to cytochalasin $\mathrm{B}$, application of the calmodulin antagonist W-7 eliminated the $\mathrm{A}_{2 \mathrm{~A}} \mathrm{R}$-mediated inhibition of NMDA-induced current in rat neostriatal neurons [83]. Using several other inhibitors of signal transduction components, the authors found that $\mathrm{A}_{2 \mathrm{~A}} \mathrm{R}$-mediated inhibition of NMDA channels occurs via a pathway involving PLC/inositol 1,4,5trisphosphate/calmodulin and calmodulin kinase II.

Remarkably, one of these signaling components, calmodulin, was recently shown to interact directly with the Cterminus of $\mathrm{A}_{2 \mathrm{~A}} \mathrm{Rs}$ [77, 84]. Calmodulin is an intracellular $\mathrm{Ca}^{2+}$-binding protein that plays a central role in $\mathrm{Ca}^{2+}$ signaling and binds the $\mathrm{A}_{2 \mathrm{~A}} \mathrm{R}$ at the membrane proximal domain including part of helix 8 . When the $A_{2 A} R$ and calmodulin were coexpressed in HEK293 cells, it was found that changes in intracellular $\mathrm{Ca}^{2+}$ lead to conformational changes in the calmodulin- $\mathrm{A}_{2 \mathrm{~A}} \mathrm{R}$ heterodimer. In addition to calmodulin, $\mathrm{A}_{2 \mathrm{~A}} \mathrm{Rs}$ have been reported to heterodimerize with other GPCRs such as the dopamine $\mathrm{D}_{2} \mathrm{R}[14,28,85]$. Calmodulin appears to interact with the $\mathrm{A}_{2 \mathrm{~A}} \mathrm{R}-\mathrm{D}_{2} \mathrm{R}$ dimer to form a calmodulin- $\mathrm{A}_{2 \mathrm{~A}} \mathrm{R}-\mathrm{D}_{2} \mathrm{R}$ oligomer [84]. Even though changes in intracellular $\mathrm{Ca}^{2+}$ lead to a conformational change in the calmodulin- $\mathrm{A}_{2 \mathrm{~A}} \mathrm{R}$ complex, variations in intracellular $\mathrm{Ca}^{2+}$ did not lead to modified ERK1/2 phosphorylation after activation of the $\mathrm{A}_{2 \mathrm{~A}} \mathrm{R}$ with CGS21680. In contrast, upon cotransfection of the $\mathrm{D}_{2} \mathrm{R}$, an increase in intracellular $\mathrm{Ca}^{2+}$ negatively influenced the ability of the calmodulin- $\mathrm{A}_{2 \mathrm{~A}} \mathrm{R}$ $\mathrm{D}_{2} \mathrm{R}$ oligomer to activate ERK1/2 upon stimulation with CGS21680, while positively modulating ERK1/2 activation after stimulation with the $\mathrm{D}_{2} \mathrm{R}$ agonist quinpirole [84]. Therefore it seems that calmodulin modulates ERK1/2 activation initiated by the calmodulin- $\mathrm{A}_{2 \mathrm{~A}} \mathrm{R}-\mathrm{D}_{2} \mathrm{R}$ oligomer, but not that of the calmodulin- $\mathrm{A}_{2 \mathrm{~A}} \mathrm{R}$ heterodimer.

ARNO, $\alpha$-actinin, and calmodulin all bind to the same domain at the $\mathrm{A}_{2 \mathrm{~A}} \mathrm{R}$ C-terminus that includes part of helix 8 , and it is unlikely that they do so simultaneously [78]. These adapter proteins may therefore interact with the $\mathrm{A}_{2 \mathrm{~A}} \mathrm{R}$ at specific time points during receptor activation, or depending on their availability in the cellular background. It can also be envisioned that certain ligands stabilize receptor conformations that favor binding of one of these adapter proteins over the others, resulting in a ligand-dependent activation of for instance ERK1/2.

\section{NECAB2 and TRAX}

In addition to calmodulin, another $\mathrm{Ca}^{2+}$-binding protein was shown to interact with the $\mathrm{C}$-terminus of the $\mathrm{A}_{2 \mathrm{~A}} \mathrm{R}$. NECAB2 is a neuronal protein that was picked up during a yeast twohybrid screen with the $\mathrm{A}_{2 \mathrm{~A}} \mathrm{R}$ C-tail as bait [76]. Increasing concentrations of $\mathrm{Ca}^{2+}$ inhibited the binding of the $\mathrm{A}_{2 \mathrm{~A}} \mathrm{R}$ to NECAB2. Coexpression of NECAB2 and $A_{2 A}$ Rs in HEK293 cells resulted in a decrease in $A_{2 A} R$ cell surface expression in combination with intracellular retention of the $A_{2 A} R$. Stimulation of cells expressing the $\mathrm{A}_{2 \mathrm{~A}} \mathrm{R}$ alone with the agonist CGS21680 resulted in a time-dependent decrease in cell surface expression of the receptor. Intriguingly, when the $\mathrm{A}_{2 \mathrm{~A}} \mathrm{R}$ and NECAB2 were coexpressed, CGS21680-treatment for $2 \mathrm{~h}$ resulted in a marked increase in cell surface expression of $\mathrm{A}_{2 \mathrm{~A}}$ Rs. In addition, coexpression of NECAB2 and $\mathrm{A}_{2 \mathrm{~A}}$ Rs significantly potentiated ERK1/2 activation after incubation with CGS21680 [76]. These results illustrate once more how binding of intracellular proteins to the $\mathrm{C}$-terminus of the $A_{2 A} R$ can influence signaling. The observation that increasing $\mathrm{Ca}^{2+}$ concentrations disrupt the interaction between the $A_{2 A} R$ and NECAB2 suggests a dynamic finetuning of $A_{2 A} R$ signaling by NECAB2, similar to the $\mathrm{Ca}^{2+}$. dependent regulation of ERK1/2 activation by the calmodulin- $\mathrm{A}_{2 \mathrm{~A}} \mathrm{R}-\mathrm{D}_{2} \mathrm{R}$ oligomer [84].

Finally, interaction of the $A_{2 A} R$ C-terminus with TRAX has been reported. It rescues the nerve growth factor (NGF)induced differentiation process impaired by inactivation of the transcription factor p53 in rat adrenal pheochromocytoma PC-12 cells, which are used as a model system for neuronal differentiation [75]. NGF induces neuronal differentiation in PC-12 cells via multiple pathways, such as the ERK1/2 and p53/p21 pathway. When the ERK1/2 pathway is blocked, stimulation of the $\mathrm{A}_{2 \mathrm{~A}} \mathrm{R}$ can rescue neuronal differentiation via a cAMP/PKA/CREB-dependent pathway in PC-12 cells [86]. However, $\mathrm{A}_{2 \mathrm{~A}} \mathrm{R}$-mediated rescue of the differentiation process when $\mathrm{p} 53$ signaling was blocked was found to be independent of PKA and to be mediated by TRAX [75]. TRAX binds to several proteins, among which translin and the kinesin heavy chain member KIF2A. KIF2A but not translin was shown to mediate the rescue effect of the $\mathrm{A}_{2 \mathrm{~A}} \mathrm{R}$ upon p53 impairment in PC-12 cells and primary rat hippocampal neurons [87]. Therefore rescue of a damaged p53 pathway, which may occur pathologically, is mediated through an $\mathrm{A}_{2 \mathrm{~A}} \mathrm{R} / \mathrm{TRAX} / \mathrm{KIF} 2 \mathrm{~A}$ pathway and may contribute to the neuronal protective effects of $\mathrm{A}_{2 \mathrm{~A}} \mathrm{Rs}$. Since p53, TRAX, and KIF2A have been implicated in schizophrenia and the $\mathrm{A}_{2 \mathrm{~A}} \mathrm{R}$ is a potential target for the treatment of schizophrenia [87], it can be speculated that selective activation of the $A_{2 A} R / T R A X$ pathway by biased agonists may be beneficial in the treatment of schizophrenia.

Summarizing, although the $A_{2 A} R$ has much potential for $\mathrm{G}$ protein-independent signaling pathways through its 
extraordinary long carboxyl terminus, to date specific regulation of these pathways by biased ligands has not been reported.

\section{$A_{2 B}$ adenosine receptors}

The $A_{2 B} R$ is described mainly as a $\mathrm{G} \alpha_{\mathrm{s}}$-coupled 7TMR [22], although coupling to $G$ proteins of the $G \alpha_{q}$ class has also been described [88-90] (Fig. 4). In the Jurkat T cell leukemia cell line, $\mathrm{Ca}^{2+}$ responses were partially sensitive to PTX, suggesting coupling to $G \alpha_{i}$ proteins as well [91]. In transfected $\mathrm{CHO}$ cells, $\mathrm{A}_{2 \mathrm{~B}} \mathrm{R}$ activation resulted in ERK1/2 activation that was slightly lower than ERK1/2 activation by the $\mathrm{A}_{2 \mathrm{~A}} \mathrm{R}$ and considerably lower than by $\mathrm{A}_{1} \mathrm{Rs}$ or $\mathrm{A}_{3} \mathrm{Rs}$ [27]. The non-selective agonist NECA stimulated ERK1/2 phosphorylation via all four adenosine receptors with nanomolar potencies, but the potency of NECA in $\mathrm{CHO}-\mathrm{A}_{2 \mathrm{~B}}$ cells for stimulating ERK1/2 (19 nM) was over 70-fold higher than for cAMP accumulation $(1.4 \mu \mathrm{M})$. Stimulation of the $\mathrm{A}_{2 \mathrm{~B}} \mathrm{R}$ with NECA in CHO cells resulted in cAMP-mediated activation of the MAPK p38 as well, with an $\mathrm{EC}_{50}$ value similar to that of ERK1/2 activation [92]. However, the pathways downstream of cAMP are different, i.e., ERK1/2 activation was mediated via PI3K, while $\mathrm{p} 38$ phosphorylation depended on PKA activity in CHO cells [92]. In human umbilical vein endothelial cells (HUVECs) ERK1/2 activation was $\mathrm{G} \alpha_{\mathrm{s}} / \mathrm{cAMP}$ mediated and not dependent on PKC, making it unlikely that $\mathrm{G} \alpha_{\mathrm{q}}$ or $\mathrm{G} \alpha_{\mathrm{i}}$ proteins are involved in this pathway [93].

Based on cAMP measurements it has previously been assumed that the $\mathrm{A}_{2 \mathrm{~B}} \mathrm{R}$ is only activated at very high, pathophysiological concentrations of adenosine, while the other three receptors are activated at physiological concentrations of adenosine. The discrepancy between potency for the cAMP and ERK1/2 pathways indicates that amplification of the ERK1/2 signal takes place, or that $\mathrm{A}_{2 \mathrm{~B}} \mathrm{R}$ preferentially activates the ERK1/2 pathway over $\mathrm{G} \alpha_{\mathrm{s}}$.

\section{$\mathrm{G}$ protein-independent interactions}

One of the non-G proteins that have been described to interact with the $\mathrm{A}_{2 \mathrm{~B}} \mathrm{R}$ is the receptor for netrin-1, also called deletedin-colorectal-cancer (DCC) [94] (Fig. 4). Netrins are secreted proteins that are important in axon guidance. Interaction of the netrin- 1 receptor DCC with the C-terminus of the $A_{2 B} R$ was found during a yeast two-hybrid screen, using the intracellular domain of DCC as bait. Interestingly netrin-1, the ligand for DCC, was shown to activate $\mathrm{A}_{2 \mathrm{~B}}$ Rs directly as well, apparently acting as a positive modulator at a site different from the binding site of the agonist NECA [94]. Netrin-1 increased binding of ${ }^{3} \mathrm{H}-\mathrm{NECA}$ to $\mathrm{A}_{2 \mathrm{~B}} \mathrm{R}$-transfected HEK293T cells in a concentration-dependent manner, which

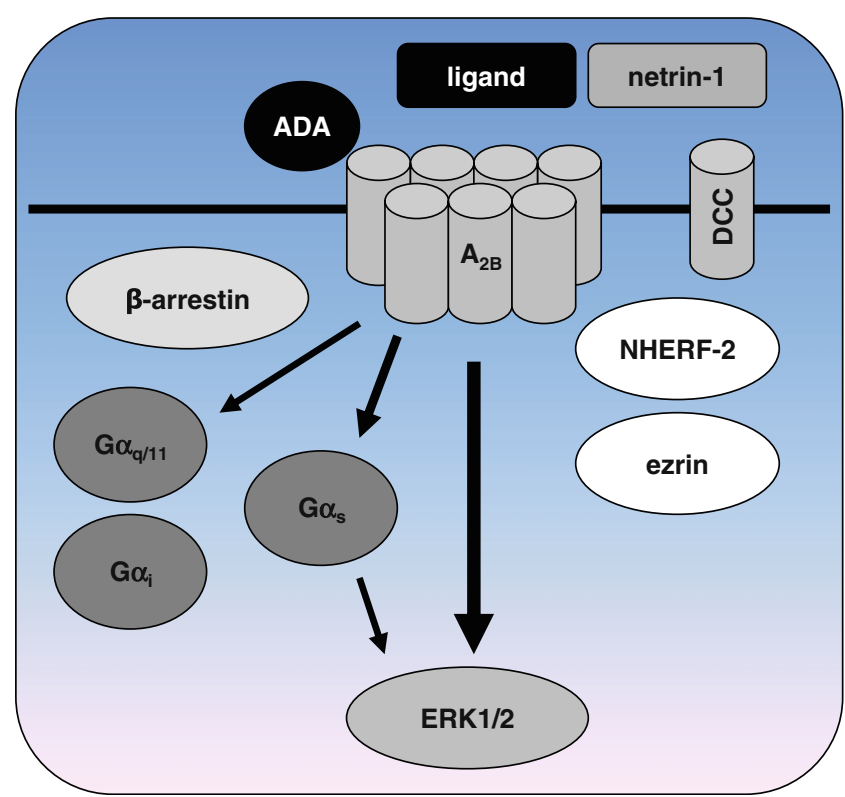

Fig. 4 Potential for functional selectivity of the adenosine $A_{2 B}$ receptor. Similar to the $\mathrm{A}_{2 \mathrm{~A}} \mathrm{R}$ no functionally selective ligands have been identified for the $\mathrm{A}_{2 \mathrm{~B}} \mathrm{R}$. Besides coupling of the $A_{2 B} R$ to $G \alpha_{s}$, coupling to $G \alpha_{q / 11}$ and possibly $G \alpha_{i}$ proteins has been described. $E R K 1 / 2$ is activated with a remarkably higher potency than observed for $\mathrm{G} \alpha_{\mathrm{s}}$ mediated cAMP accumulation, indicating divergent signal transduction pathways that potentially can be regulated with biased ligands. Interaction with the extracellular proteins $A D A$ and netrin or with the membrane-bound netrin-receptor $D C C$ may influence $\mathrm{A}_{2 \mathrm{~B}} \mathrm{R}$ signaling in an allosteric manner. In addition, $D C C$ and $\mathrm{A}_{2 \mathrm{~B}} \mathrm{R}$ both bind the intracellular proteins ezrin and NHERF-2 that may be involved in anchoring $\mathrm{A}_{2 \mathrm{~B}} \mathrm{R}$ to the cytoskeleton and/or forming a signaling complex. See references in the text for more detailed information

is an indication of allosteric modulation of $\mathrm{A}_{2 \mathrm{~B}} \mathrm{R}$ by netrin-1. In HEK293T cells transfected with the $\mathrm{A}_{2 \mathrm{~B}} \mathrm{R}$, both addition of NECA and coexpression of the secreted protein netrin-1 resulted in increased cAMP levels. When NECA was added to HEK293T cells coexpressing both the $\mathrm{A}_{2 \mathrm{~B}} \mathrm{R}$ and netrin-1, an additive effect of NECA and netrin-1 on cAMP accumulation was observed. Similarly, in the DCC-deficient adenocarcinoma HCT8/S11 cell line simultaneous addition of NECA and netrin-1 resulted in additive pro-invasive activity, although no significant additive effects on cAMP generation were observed [95]. This suggests that netrin-1 may act as an allosteric modulator of $\mathrm{A}_{2 \mathrm{~B}} \mathrm{R}$-mediated pro-invasive activity but not cAMP accumulation, or that netrin- 1 and $\mathrm{A}_{2 \mathrm{~B}} \mathrm{Rs}$ activate distinct but convergent signaling pathways to induce invasion in HCT8/S11 cells. It was found that the $A_{2 B} R$ is directly involved in netrin-1-dependent outgrowth of dorsal spinal cord axons [94], a finding that later was disputed by another group [96]. A direct interaction of netrin-1 with the $\mathrm{A}_{2 \mathrm{~B}} \mathrm{R}$ was also suggested to be involved in the modulation of transepithelial migration of polymorphonuclear neutrophils (PMNs) [97]. In PMNs, the $\mathrm{A}_{2 \mathrm{~B}} \mathrm{R}$ antagonist PSB1115 19 
blocked netrin-1-mediated increases in cAMP concentrations, indicating that netrin-1 directly interacts with $\mathrm{A}_{2 \mathrm{~B}} \mathrm{Rs}$ [97].

Others reported that the $\mathrm{A}_{2 \mathrm{~B}} \mathrm{R}$ does not bind netrin-1, but that $\mathrm{A}_{2 \mathrm{~B}} \mathrm{R}$ activity by itself can regulate axonal responses to netrin-1 [98]. Activation of the $\mathrm{A}_{2 \mathrm{~B}} \mathrm{R}$ by the agonists MECA 20 and NECA or by $A_{2 B} R$ overexpression was found to be responsible for downregulation of another netrin-1 receptor named UNC5A, thereby modulating netrin-1 responses [98]. Additional support for an interaction between the netrin- 1 receptor DCC and $\mathrm{A}_{2 \mathrm{~B}} \mathrm{Rs}$ is the fact that they interact with the same proteins. DCC was shown to interact with ezrin, a PKA-anchoring protein that is associated with the actin cytoskeleton [99]. Interestingly, the human $\mathrm{A}_{2 \mathrm{~B}} \mathrm{R}$ also associates with ezrin upon activation with adenosine, as well as with NHERF-2 $\left(\mathrm{Na}^{+} / \mathrm{H}^{+}\right.$ exchanger regulatory factor 2) [100]. It was suggested that the $\mathrm{A}_{2 \mathrm{~B}} \mathrm{R}$ may be anchored to the membrane by NHERF-2, and form a signaling complex with ezrin, adenylate cyclase, and PKA [100]. Through its interaction with ezrin, DCC may also be part of this complex. In contrast, the rat $\mathrm{A}_{2 \mathrm{~B}} \mathrm{R}$ co-immunoprecipitates with NHERF-1 and this interaction is reduced upon activation with the agonist NECA [101]. Overexpression of NHERF-1 inhibited internalization of rat $\mathrm{A}_{2 \mathrm{~B}} \mathrm{Rs}$ and a role for this scaffolding protein in rat $\mathrm{A}_{2 \mathrm{~B}} \mathrm{R}$ recycling has been proposed [101].

Taken together, there is evidence that the $\mathrm{A}_{2 \mathrm{~B}} \mathrm{R}$ is involved in netrin-1 signaling. It is however not clear if this occurs through a direct interaction of netrin- 1 and the $\mathrm{A}_{2 \mathrm{~B}} \mathrm{R}$, the involvement of an $\mathrm{A}_{2 \mathrm{~B}} \mathrm{R} / \mathrm{DCC} /$ netrin-1 complex or $\mathrm{A}_{2 \mathrm{~B}} \mathrm{R}$ mediated modulation of netrin-1 receptor expression levels. If netrin-1 or DCC indeed acts as allosteric modulators of $\mathrm{A}_{2 \mathrm{~B}} \mathrm{Rs}$ [94], it may well be possible to influence such a complex with functionally selective ligands.

Furthermore, the $\mathrm{A}_{2 \mathrm{~B}} \mathrm{R}$ has been described to interact with proteins involved in desensitization, internalization, and intracellular trafficking, such as $\beta$-arrestin- 1 and $\beta$-arrestin2 [102, 103], vesicle-associated membrane protein [104] and soluble NEM-sensitive factor attachment protein [104]. An intact $\mathrm{C}$-terminal PDZ motif of the rat $\mathrm{A}_{2 \mathrm{~B}} \mathrm{R}$ was found to be important for $\beta$-arrestin-1 and clathrin-mediated internalization, while disruption of this motif did not affect dynamindependent internalization [101]. This stresses the importance of the interaction of the intracellular tail of the $\mathrm{A}_{2 \mathrm{~B}} \mathrm{R}$ with adapter proteins and the possible opportunities to intervene in these processes with functionally selective ligands.

Besides protein-protein interactions with the intracellular domain of the $\mathrm{A}_{2 \mathrm{~B}} \mathrm{R}$, the extracellular parts of $\mathrm{A}_{2 \mathrm{~B}}$ Rs were shown to bind to ADA [105], similar to the findings for the $A_{1} R[52,53]$. Whereas cell surface expression of endogenous ADA is not detectable on control $\mathrm{CHO}$ cells, transfection of $\mathrm{CHO}$ cells with the $\mathrm{A}_{2 \mathrm{~B}} \mathrm{R}$ results in extracellular expression of ADA [105]. Total binding of ${ }^{3} \mathrm{H}-\mathrm{NECA}$ to $\mathrm{CHO}$ cells transfected with the $\mathrm{A}_{2 \mathrm{~B}} \mathrm{R}$ was concentration-dependently enhanced by addition of ADA, and the affinity of NECA was increased in the presence of ADA. In addition, cAMP production by NECA was increased as well in the presence of ADA. These results point toward an allosteric modulation of $\mathrm{A}_{2 \mathrm{~B}} \mathrm{Rs}$ by $\mathrm{ADA}$, similar as was found for the interaction of ADA with the $\mathrm{A}_{1} \mathrm{R}$ [54].

Despite the apparent potential of $\mathrm{A}_{2 \mathrm{~B}} \mathrm{Rs}$ to engage functional selectivity through activation of different classes of $G$ proteins, interactions with $\beta$-arrestins or allosteric modulation at intracellular and extracellular sites, no ligands have been reported that selectively employ these pathways.

\section{$A_{3}$ adenosine receptors}

$A_{3}$ Rs couple primarily to proteins of the $G \alpha_{i}$ class $\left(G \alpha_{i 2}\right.$ and $\left.\mathrm{G} \alpha_{\mathrm{i} 3}\right)$ and to a lesser extent to $\mathrm{G} \alpha_{\mathrm{q} / 11}$ [106]. Signaling by $\mathrm{A}_{3} \mathrm{Rs}$ in A6 renal epithelial cells is PTX insensitive and was suggested to be mediated by $G \alpha_{s}$ proteins [107] (Fig. 5).

The $A_{3} R$ has been described as enigmatic, in the sense that many of the effects ascribed to $\mathrm{A}_{3} \mathrm{Rs}$ are contradictory, such as neuroprotection vs. neurodegradation, cardioprotection vs. cardiotoxicity, anti-inflammatory vs. proinflammatory, immunosuppression vs. immunostimulation and pro- vs. anti-apoptotic effects [108]. In addition, there are quite some remarkable differences in expression, sequence homology and affinity of ligands between human and rodent $A_{3} R s$, complicating thorough characterization of these receptors.

The $A_{3} R$ contains a potential nuclear localization motif in its intracellular helix 8 , suggesting that the receptor may interact with proteins involved in nuclear transport [109]. $\mathrm{A}_{3} \mathrm{Rs}$ on the nuclear membrane may be activated by intracellular adenosine and interact with nuclear $G$ proteins or nuclear $\beta$-arrestin-1. Although nuclear expression of $A_{3} R$ has to be experimentally validated, signaling by intracellular receptors is a possible new area where functionally selective ligands may be of use [110].

Biphasic effects at high agonist concentrations

The effects of $A_{3} R$-specific agonists such as IB-MECA 21 and Cl-IB-MECA 22 on proliferation have been described as being biphasic, e.g., preventing apoptosis at low $(1 \mu \mathrm{M})$ concentrations, and inducing apoptosis at very high (10$100 \mu \mathrm{M})$ concentrations [111, 112] (Fig. 5). Biphasic stimulation of ERK1/2 was also observed in the mouse N13 microglia cell line, where low concentrations of Cl-IBMECA or NECA stimulated ERK1/2 phosphorylation in a PTX-sensitive manner, while higher concentrations 


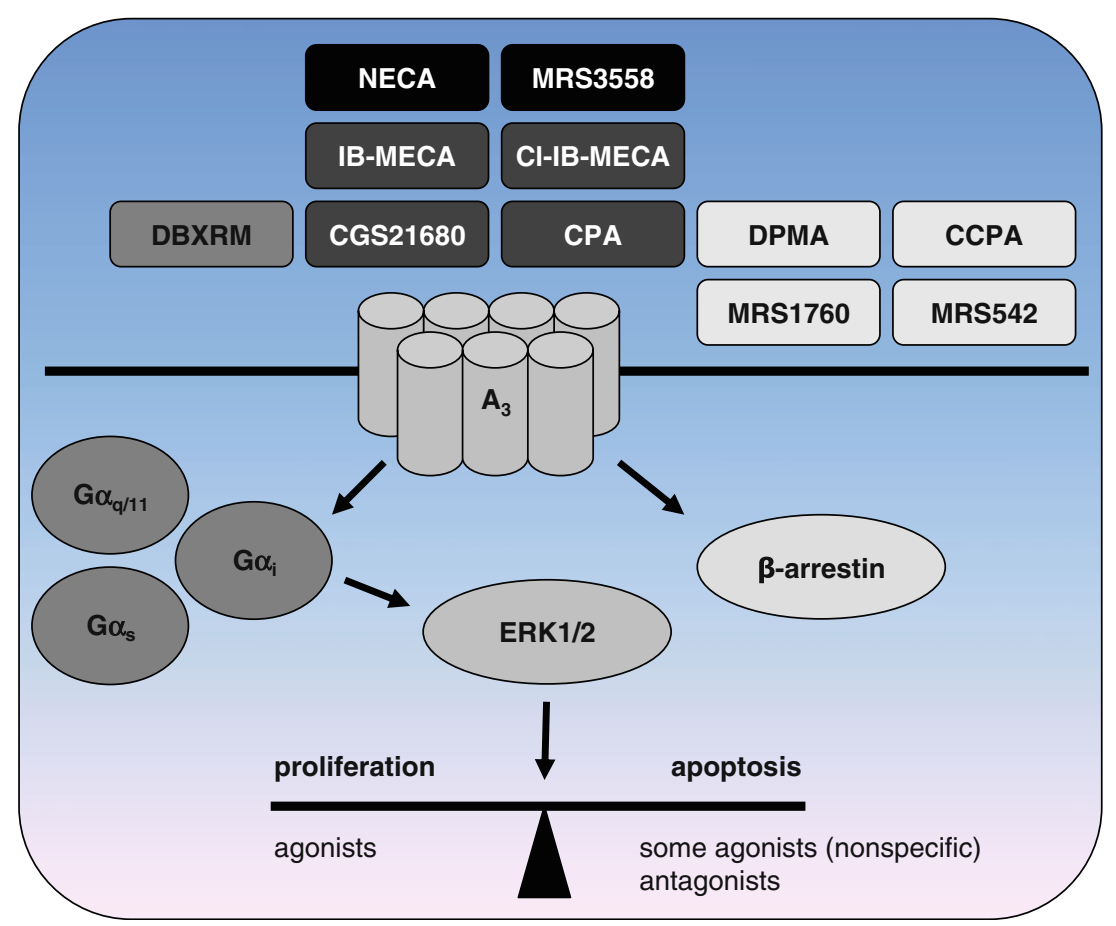

Fig. 5 Functional selectivity of the adenosine $A_{3}$ receptor. Ligands with a bias towards $\beta$-arrestin-mediated signaling versus a $G \alpha_{i}$-dependent pathway have been identified. Ligands that are antagonists for $G \alpha_{i^{-}}$ mediated cAMP inhibition such as DMPA, CCPA, MRS1760, and MRS542 act as partial agonists for $\beta$-arrestin translocation. Interestingly, amongst the compounds that act as full agonists for both pathways, i.e., $N E C A, M R S 3558, I B-M E C A, C l-I B-M E C A, C G S 21680$, and CPA, both the nonspecific agonist $N E C A$ and the $\mathrm{A}_{3} \mathrm{R}$-specific agonist $M R S 3558$

$(\geq 10 \mu \mathrm{M})$ were without effect [113]. Also, Cl-IB-MECA inhibited proliferation and ERK1/2 phosphorylation in A375 human melanoma cells at high $(10 \mu \mathrm{M})$ concentrations [114]. Such a biphasic effect was not observed when $\mathrm{A}_{3} \mathrm{R}$-transfected $\mathrm{CHO}$ cells were stimulated with increasing concentrations of NECA, which resulted in a sigmoidal increase in ERK1/2 activation [27, 115]. It is therefore unclear if the observed biphasic signals should be contributed to the stimulation of another pathway by $\mathrm{A}_{3} \mathrm{Rs}$ at higher agonist concentrations, to rapid desensitization of the receptor at higher agonist concentrations, non-selective activation of other adenosine receptors or other pathways, or a combination of the above.

There however is evidence that the effects of high concentrations of certain $A_{3} R$ agonists are $A_{3} R$ independent. For instance, in the human papillary thyroid carcinoma NPA cell line the agonist Cl-IB-MECA inhibited cell growth at high concentrations with an $\mathrm{IC}_{50}$ of $38 \mu \mathrm{M}$ [116]. ERK $1 / 2$ phosphorylation was rapidly reduced by $40 \mu \mathrm{M}$ Cl-IB-MECA and this effect was not blocked after preincubation with the antagonists MRS1523 $23(10 \mu \mathrm{M})$ or FA385 $24(5 \mu \mathrm{M})$. Similar anti-proliferative effects of high concentrations of Cl-IB-MECA $(30 \mu \mathrm{M})$ were reported in human leukemic cell lines HL-60 and show faster $\beta$-arestin translocation rates. DBXRM, a full agonist for the $G \alpha_{i}$ pathway, was a partial agonist for $\beta$-arrestin signaling. Besides these evident examples of functional selectivity, there are conflicting reports of the effects $\mathrm{A}_{3} \mathrm{R}$ ligands have on apoptosis and proliferation. Since in many of these studies very high ligand concentrations were used, care must be taken when drawing conclusions about biased effects on cell growth. See references in the text for more detailed information

MOLT-4 in the presence of the antagonists MRS1523 23 $(10 \mu \mathrm{M})$ or MRS1220 $25(5 \mu \mathrm{M})$ [117]. An $\mathrm{A}_{3} \mathrm{R}$ agonist that is structurally related to Cl-IB-MECA, the ringconstrained N-methanocarba nucleoside MRS1898 26 [118], did not induce apoptosis at high micromolar concentrations [117]. In addition, IB-MECA $(100 \mu \mathrm{M})$ suppressed proliferation in a variety of human breast cancer cells which do not have detectable levels of $\mathrm{A}_{3} \mathrm{R}$ mRNA, while incubation with Cl-IB-MECA $(100 \mu \mathrm{M})$ killed the cells [119]. Adenosine 1 and several adenosine analogs such as 3 'dA (Cordycepin) 2, 2CdA (Cladribine) 3, and CADO 4 also inhibited growth of human breast cancer cells [119]. These findings suggest that the antiproliferative effects of high concentrations of certain $\mathrm{A}_{3} \mathrm{R}$ agonists such as IB-MECA and Cl-IB-MECA are $\mathrm{A}_{3} \mathrm{R}$ independent and may be specific to a certain class of $A_{3} R$ agonists and/or cancer cells. Therefore, these biphasic effects are likely not indicative of biased signaling at higher concentrations of agonists.

Antagonist-mediated effects

Surprisingly, incubation of human HL-60 leukemia or U937 lymphoma cell lines with relatively low concentrations 
of the antagonists MRS $119128(0.5 \mu \mathrm{M}), \mathrm{L}-24931329$ $(0.5 \mu \mathrm{M})$ or MRS $122025(10 \mathrm{nM})$ resulted in reduced cell growth and apoptosis, which were reversed by addition of low concentrations of agonists [120]. A more recent study showed anti-proliferative and apoptotic effects of an antagonist at high concentrations $(30-50 \mu \mathrm{M})$ in $\mathrm{T} 24$ human bladder cancer cells [121]. This truncated analog of Cl-IB-MECA, named truncated thio-Cl-IB-MECA $\mathbf{3 0}$, induced cell cycle arrest and regulation of several cell cycle and apoptosis related proteins, ERK1/2 and JNK at $50 \mu \mathrm{M}$. With the use of pharmacological inhibitors a role for ERK1/ 2 and $\mathrm{JNK}$ in $\mathrm{A}_{3} \mathrm{R}$-antagonist induced apoptosis was implicated [121]. The fact that antagonists induced apoptosis suggests that there is a basal tone of the receptor, either because of constitutive activity or endogenous adenosine. This observation may also be an indication of functional selectivity, where the "antagonists" activate other pathways than the prototypical agonists. The latter option however is less likely because three antagonists (MRS1220 25, MRS1191 28, and L-249313 29) of different chemical classes showed the apoptotic effect in the same study [120].

\section{Functional selectivity of $\mathrm{A}_{3}$ adenosine receptors}

Clear evidence for functional selectivity of $\mathrm{A}_{3} \mathrm{R}$ ligands at the human receptor was provided by Gao et al. [122]. This group compared ligand-induced efficacy of PTX-insensitive $\beta$ arrestin translocation with previously reported efficacies for the $\mathrm{G} \alpha_{\mathrm{i}}$-mediated inhibition of cAMP. They used $\mathrm{CHO}$ PathHunter ${ }^{\mathrm{TM}}$ cells that express a modified $\mathrm{A}_{3} \mathrm{R}$ with a $\mathrm{C}$ terminally fused enzyme fragment and $\beta$-arrestin fused to an $\mathrm{N}$-terminal deletion mutant of $\beta$-galactosidase. Upon stimulation of the $A_{3} R$ the engineered $\beta$-arrestin interacts with the enzyme fragment linked to the $A_{3} R$, resulting in the formation of a functional $\beta$-galactosidase enzyme that converts a substrate into a detectable signal. Most of the tested compounds that were full agonists at the $\mathrm{G} \alpha_{i}$ pathway such as CPA 5, NECA 8, CGS21680 17, IB-MECA 21, ClIB-MECA 22, and MRS3558 27 acted as full agonists in the $\beta$-arrestin assay as well (Fig. 5). The rates of $A_{3} R$ translocation induced by NECA 8 and MRS3558 27 were higher than those of IB-MECA 21 and Cl-IB-MECA 22, whilst the efficacy for $\beta$-arrestin translocation of all these compounds was $100 \%$. In addition to the rate of $\beta$-arrestin translocation, the efficacy of NECA 8 for $\mathrm{Ca}^{2+}$ mobilization was also higher than that of Cl-IB-MECA 22, indicating substantial differences in the mode of action of these ligands.

Most interestingly, several compounds that acted as antagonists in the cAMP assay amongst which DPMA 31, CCPA 32, MRS1760 33, and MRS542 34 were partial agonists for $\beta$-arrestin recruitment (Fig. 5). This is a clear indication that these ligands are functionally selective at the $A_{3} R$. The opposite, i.e., full agonism for $\beta$-arrestin versus partial agonism or antagonism for the $\mathrm{G} \alpha_{\mathrm{i}}$-mediated pathway, was not observed for any of the compounds tested.

Activation of ERK1/2 by the $\mathrm{A}_{3} \mathrm{R}$ in the $\mathrm{CHO}$ PathHunter $^{\mathrm{TM}}$ cells was completely $\mathrm{G}_{\mathrm{i}}$-mediated, as was previously shown for $\mathrm{A}_{3} \mathrm{R}$-mediated responses in $\mathrm{CHO}$ cells [123]. This indicates that $\beta$-arrestin-mediated signaling is not involved in ERK1/2 activation in CHO cells. DBXRM 35, which was a full agonist for the $\mathrm{G} \alpha_{\mathrm{i}}$-mediated pathway, behaved as a partial agonist for $\beta$-arrestin recruitment, another indication of engagement of functionally selective pathways by $A_{3} R$ ligands. In order to determine if the difference in efficacy of DBXRM has functional consequences, $\mathrm{CHO}$ Pathhunter ${ }^{\mathrm{TM}}$ cells were desensitized for $24 \mathrm{~h}$ with DBXRM 35 (full agonist for $\mathrm{G} \alpha_{\mathrm{i}}$ and a partial agonist for $\beta$-arrestin) or with IB-MECA 21 (full agonist at both pathways) and ERK1/2 activation by the full agonist MRS3558 27 was determined. Cells incubated with DBXRM 35 showed higher ERK1/2 activation (less desensitization) than cells desensitized with IB-MECA 21, indicating that activation of the $\beta$-arrestin pathway is involved in $A_{3} R$ desensitization in these cells.

The rat $\mathrm{A}_{3} \mathrm{R}$ was shown to redistribute a GFP-tagged version of $\beta$-arrestin- 2 to small punctuate spots located both near the plasma membrane and within the cytoplasm after stimulation with R-PIA in CHO cells [40]. However, there was no significant overlap of $\beta$-arrestin- 2 and the rat $A_{3} R$. In contrast to these findings, when rat basophilic leukemia (RBL-2H3) cells, which express high levels of the rat $A_{3} R$, were stimulated with NECA no changes in the distribution of $\beta$-arrestin-1 or $\beta$-arrestin- 2 were observed [124].

It is noteworthy that the internalization rate of rat $\mathrm{A}_{3}$ Rs was found to be dependent on cysteine residues C302 and C305 downstream of helix 8 in the carboxyl terminus of the receptor that are thought to anchor the carboxyl terminus to the membrane through palmitoylation [40]. When these cysteines were mutated to alanines that cannot undergo palmitoylation, the rat $\mathrm{A}_{3} \mathrm{R}$ underwent more rapid internalization upon stimulation with R-PIA. The same study also showed that internalization is critically dependent on three C-terminal GRK phosphorylation sites. Moreover, mutation of the cysteine residues to alanine resulted in a basal phosporylation of the rat $A_{3} R$ [125]. Since receptor phosphorylation, $\beta$-arrestin recruitment, and internalization usually are highly dependent upon each other, one could speculate that the faster rates of $\beta$-arrestin translocation induced by NECA and MRS3558 compared to IB-MECA and Cl-IB-MECA [122] reflect different conformations of the $\mathrm{C}$-terminus of the receptor induced by these compounds, which allow faster phosphorylation and/or interaction with $\beta$-arrestin. Another possibility is that these functionally selective agonists differentially promote palmitate removal, resulting in a receptor that is more susceptible to phosphorylation and interaction with $\beta$-arrestins. 


\section{Conclusion and perspectives}

Functional selectivity of synthetic ligands has been convincingly shown for the $A_{1} R$ and $A_{3} R$. In case of the $A_{1} R$, ligands induced differential coupling to $G$ proteins, whereas $A_{3} R$ ligands can selectively activate either $G$ protein or $\beta$-arrestin pathways. All adenosine receptors have been shown to interact with proteins additional to $G$ proteins such as $\beta$-arrestins or other scaffold proteins. Since binding of cytosolic scaffold proteins to the intracellular domains of 7TMRs is expected to induce distinct conformations that theoretically can lead to a functionally selective response via these adapter proteins, it is remarkable that biased signaling through scaffold proteins has not been observed to date for adenosine receptors. Especially, the $\mathrm{A}_{2 \mathrm{~A}} \mathrm{R}$ binds a wide variety of scaffold proteins and would be expected to be able to mediate a functionally selective response through these proteins. However, many of the studies described in this review that investigated $G$ protein-independent signal transduction used only the classical subtype-selective agonists, or promiscuous ligands such as NECA. This is particularly true for studies investigating novel pathways such as those mediated by scaffold proteins. The assays deployed to study alternative $G$ protein-independent pathways are often tedious and not readily suitable for the screening of compound libraries. This may have contributed to the lack of data describing functional selectivity mediated by scaffold proteins. Although there are several examples where stimulation with an agonist enhances the interaction of a given GPCR with a scaffold protein other than $\beta$-arrestin [7], to our knowledge there are no cases where this leads to a truly biased response. This makes one wonder if the theoretical mechanism of biased responses through scaffolding proteins other than $\beta$-arrestins is physiologically relevant, or is just overlooked because it has not been tested so far.

Functional selectivity is a relatively new phenomenon, due to the fact that the experimental techniques needed to distinguish between signal transduction pathways became only recently available. In classical organ bath experiments where contraction of a tissue is used as final and integrated readout of agonistic signaling, differential signaling between $G$ protein and $\beta$-arrestin went unnoticed. Only with the use of sensitive cellular assays and molecular biology it became possible to study the individual signal transduction pathways that may lead to a final response such as contraction of a tissue. Surprisingly, the new method of choice to identify novel biased ligands may be a technique that relies on studying an integrated response after all, instead of individual pathways. In this case, the readout is a change in cellular morphology upon 7TMR-mediated signaling, caused by rearrangements of the cytoskeleton. The altered morphology can be detected using label-free techniques such as variation in cellular impedance [126].
Label-free techniques nowadays are sensitive enough to distinguish between $G$ protein families and eliminate the need to perform multiple assays in order to detect divergent signaling pathways.

Since the discovery of adenosine receptors, a large array of synthetic agonists, inverse agonists, antagonists, and allosteric modulators for these 7TMRs has been reported. Most of these compounds have only been validated using classical second messenger assays such as stimulation or inhibition of cAMP accumulation. It is most likely that there will be compounds with hitherto unrecognized functionally selective properties among this large ligand library. The identification and characterization of these compounds may identify new therapeutic opportunities for old drugs.

Acknowledgments We are grateful for the financial support provided by the Dutch Top Institute Pharma (project D1-105)

Open Access This article is distributed under the terms of the Creative Commons Attribution Noncommercial License which permits any noncommercial use, distribution, and reproduction in any medium, provided the original author(s) and source are credited.

\section{References}

1. Kristiansen K (2004) Molecular mechanisms of ligand binding, signaling, and regulation within the superfamily of G-proteincoupled receptors: molecular modeling and mutagenesis approaches to receptor structure and function. Pharmacol Ther 103(1):21-80

2. Milligan G, Kostenis E (2006) Heterotrimeric G-proteins: a short history. Br J Pharmacol 147(Suppl 1):S46-55

3. Schmid CL, Bohn LM (2009) Physiological and pharmacological implications of beta-arrestin regulation. Pharmacol Ther 121 (3):285-293

4. Oakley RH, Laporte SA, Holt JA, Caron MG, Barak LS (2000) Differential affinities of visual arrestin, ßarrestin1, and $\beta$ arrestin2 for $\mathrm{G}$ protein-coupled receptors delineate two major classes of receptors. J Biol Chem 275(22):17201-17210

5. Kohout TA, Lin FS, Perry SJ, Conner DA, Lefkowitz RJ (2001) $\beta$-Arrestin 1 and 2 differentially regulate heptahelical receptor signaling and trafficking. Proc Natl Acad Sci USA 98(4):16011606

6. Rajagopal S, Rajagopal K, Lefkowitz RJ (2010) Teaching old receptors new tricks: biasing seven-transmembrane receptors. Nat Rev Drug Discov 9(5):373-386

7. Hall RA, Lefkowitz RJ (2002) Regulation of G protein-coupled receptor signaling by scaffold proteins. Circ Res 91(8):672-680

8. Patel CB, Noor N, Rockman HA (2010) Functional selectivity in adrenergic and angiotensin signaling systems. Mol Pharmacol 78 (6):983-992

9. Zhang M, Liu X, Zhang Y, Zhao J (2010) Loss of ßarrestin1 and ßarrestin2 contributes to pulmonary hypoplasia and neonatal lethality in mice. Dev Biol 339(2):407-417

10. Kenakin T (2011) Functional selectivity and biased receptor signaling. J Pharmacol Exp Ther 336(2):296-302

11. Kenakin T, Miller LJ (2010) Seven transmembrane receptors as shapeshifting proteins: the impact of allosteric modulation and functional selectivity on new drug discovery. Pharmacol Rev 62 (2):265-304 
12. May LT, Leach K, Sexton PM, Christopoulos A (2007) Allosteric modulation of $\mathrm{G}$ protein-coupled receptors. Annu Rev Pharmacol Toxicol 47:1-51

13. Göblyös A, IJzerman AP (2011) Allosteric modulation of adenosine receptors. Biochim Biophys Acta 1808(5):1309-1318

14. Fredholm BB, IJzerman AP, Jacobson KA, Linden J, Müller CE (2011) International Union of Basic and Clinical Pharmacology. LXXXI. Nomenclature and Classification of Adenosine Receptorsan update. Pharmacol Rev 63(1):1-34

15. Walters RW, Shukla AK, Kovacs JJ, Violin JD, DeWire SM, Lam CM, Chen JR, Muehlbauer MJ, Whalen EJ, Lefkowitz RJ (2009) $\beta$-Arrestin1 mediates nicotinic acid-induced flushing, but not its antilipolytic effect, in mice. J Clin Invest 119(5):1312-1321

16. Semple G, Skinner PJ, Gharbaoui T, Shin YJ, Jung JK, Cherrier MC, Webb PJ, Tamura SY, Boatman PD, Sage CR, Schrader TO, Chen R, Colletti SL, Tata JR, Waters MG, Cheng K, Taggart AK, Cai TQ, Carballo-Jane E, Behan DP, Connolly DT, Richman JG (2008) 3-(1 $H$-tetrazol-5-yl)-1,4,5,6-tetrahydro-cyclopentapyrazole (MK-0354): a partial agonist of the nicotinic acid receptor, G-protein coupled receptor $109 \mathrm{a}$, with antilipolytic but no vasodilatory activity in mice. J Med Chem 51(16):5101-5108

17. Melief EJ, Miyatake M, Bruchas MR, Chavkin C (2010) Liganddirected c-Jun N-terminal kinase activation disrupts opioid receptor signaling. Proc Natl Acad Sci USA 107(25):1160811613

18. Sun Y, Huang J, Xiang Y, Bastepe M, Juppner H, Kobilka BK, Zhang JJ, Huang XY (2007) Dosage-dependent switch from G protein-coupled to G protein-independent signaling by a GPCR. EMBO J 26(1):53-64

19. Kohout TA, Nicholas SL, Perry SJ, Reinhart G, Junger S, Struthers RS (2004) Differential desensitization, receptor phosphorylation, beta-arrestin recruitment, and ERK1/2 activation by the two endogenous ligands for the $\mathrm{CC}$ chemokine receptor 7. J Biol Chem 279(22):23214-23222

20. Zidar DA, Violin JD, Whalen EJ, Lefkowitz RJ (2009) Selective engagement of $\mathrm{G}$ protein coupled receptor kinases (GRKs) encodes distinct functions of biased ligands. Proc Natl Acad Sci USA 106(24):9649-9654

21. Fredholm BB, IJzerman AP, Jacobson KA, Klotz KN, Linden J (2001) International Union of Pharmacology. XXV. Nomenclature and classification of adenosine receptors. Pharmacol Rev 53 (4):527-552

22. Fredholm BB, Abbracchio MP, Burnstock G, Daly JW, Harden TK, Jacobson KA, Leff P, Williams M (1994) Nomenclature and classification of purinoceptors. Pharmacol Rev 46(2):143-156

23. Yang D, Zhang Y, Nguyen HG, Koupenova M, Chauhan AK, Makitalo M, Jones MR, St Hilaire C, Seldin DC, Toselli P, Lamperti E, Schreiber BM, Gavras H, Wagner DD, Ravid K (2006) The $\mathrm{A}_{2 \mathrm{~B}}$ adenosine receptor protects against inflammation and excessive vascular adhesion. J Clin Invest 116(7):1913-1923

24. Klaasse EC, IJzerman AP, de Grip WJ, Beukers MW (2008) Internalization and desensitization of adenosine receptors. Purinergic Signal 4(1):21-37

25. Müller CE, Jacobson KA (2010) Recent developments in adenosine receptor ligands and their potential as novel drugs. Biochim Biophys Acta 1808(5):1290-1308

26. Schulte G, Fredholm BB (2003) Signalling from adenosine receptors to mitogen-activated protein kinases. Cell Signal 15(9):813-827

27. Schulte G, Fredholm BB (2000) Human adenosine $A_{1}, A_{2 A}$, $A_{2 B}$, and $A_{3}$ receptors expressed in Chinese hamster ovary cells all mediate the phosphorylation of extracellular-regulated kinase 1/2. Mol Pharmacol 58(3):477-482

28. Ferre S, Ciruela F, Quiroz C, Lujan R, Popoli P, Cunha RA, Agnati LF, Fuxe K, Woods AS, Lluis C, Franco R (2007) Adenosine receptor heteromers and their integrative role in striatal function. Scientific World Journal 7:74-85
29. Jockers R, Linder ME, Hohenegger M, Nanoff C, Bertin B, Strosberg AD, Marullo S, Freissmuth M (1994) Species difference in the $G$ protein selectivity of the human and bovine $\mathrm{A}_{1}$-adenosine receptor. J Biol Chem 269(51):32077-32084

30. Dickenson JM, Hill SJ (1998) Involvement of G-protein $\beta \gamma$ subunits in coupling the adenosine $A_{1}$ receptor to phospholipase $\mathrm{C}$ in transfected CHO cells. Eur J Pharmacol 355(1):85-93

31. Cordeaux Y, Briddon SJ, Megson AE, McDonnell J, Dickenson JM, Hill SJ (2000) Influence of receptor number on functional responses elicited by agonists acting at the human adenosine $\mathrm{A}_{1}$ receptor: evidence for signaling pathway-dependent changes in agonist potency and relative intrinsic activity. Mol Pharmacol 58 (5): $1075-1084$

32. Lee JW, Joshi S, Chan JS, Wong YH (1998) Differential coupling of $\mu-, \delta$-, and $\kappa$-opioid receptors to $\mathrm{G} \alpha_{16}$-mediated stimulation of phospholipase C. J Neurochem 70(5):2203-2211

33. Cordeaux Y, IJzerman AP, Hill SJ (2004) Coupling of the human $A_{1}$ adenosine receptor to different heterotrimeric $G$ proteins: evidence for agonist-specific G protein activation. Br J Pharmacol 143 (6):705-714

34. Ballesteros JA, Weinstein H (1995) Integrated methods for the construction of three dimensional models and computational probing of structure-function relations in G-protein coupled receptors. Methods in Neuroscience 25:366-428

35. Rivkees SA, Barbhaiya H, IJzerman AP (1999) Identification of the adenine binding site of the human $\mathrm{A}_{1}$ adenosine receptor. $\mathrm{J}$ Biol Chem 274(6):3617-3621

36. Liu AM, Wong YH (2004) $\mathrm{G}_{16}$-mediated activation of nuclear factor $\mathrm{KB}$ by the adenosine $\mathrm{A}_{1}$ receptor involves $\mathrm{c}-\mathrm{Src}$, protein kinase C, and ERK signaling. J Biol Chem 279(51):53196-53204

37. Aurelio L, Valant C, Flynn BL, Sexton PM, Christopoulos A, Scammells PJ (2009) Allosteric modulators of the adenosine $A_{1}$ receptor: synthesis and pharmacological evaluation of 4-substituted 2-amino-3-benzoylthiophenes. J Med Chem 52(14):4543-4547

38. Aurelio L, Figler H, Flynn BL, Linden J, Scammells PJ (2008) 5-Substituted 2-aminothiophenes as $\mathrm{A}_{1}$ adenosine receptor allosteric enhancers. Bioorg Med Chem 16(3):1319-1327

39. Valant C, Aurelio L, Urmaliya VB, White P, Scammells PJ, Sexton PM, Christopoulos A (2010) Delineating the mode of action of adenosine $A_{1}$ receptor allosteric modulators. Mol Pharmacol 78(3):444-455

40. Ferguson G, Watterson KR, Palmer TM (2002) Subtype-specific regulation of receptor internalization and recycling by the carboxylterminal domains of the human $\mathrm{A}_{1}$ and rat $\mathrm{A}_{3}$ adenosine receptors: consequences for agonist-stimulated translocation of arrestin3. Biochemistry 41(50): 14748-14761

41. Jajoo S, Mukherjea D, Kumar S, Sheth S, Kaur T, Rybak LP, Ramkumar V (2010) Role of $\beta$-arrestin1/ERK MAP kinase pathway in regulating adenosine $A_{1}$ receptor desensitization and recovery. Am J Physiol Cell Physiol 298(1):C56-65

42. Germack R, Dickenson JM (2005) Adenosine triggers preconditioning through MEK/ERK1/2 signalling pathway during hypoxia/reoxygenation in neonatal rat cardiomyocytes. J Mol Cell Cardiol 39(3):429-442

43. Reid EA, Kristo G, Yoshimura Y, Ballard-Croft C, Keith BJ, Mentzer RM Jr, Lasley RD (2005) In vivo adenosine receptor preconditioning reduces myocardial infarct size via subcellular ERK signaling. Am J Physiol Heart Circ Physiol 288(5):H2253-2259

44. Germack R, Dickenson JM (2004) Characterization of ERK1/2 signalling pathways induced by adenosine receptor subtypes in newborn rat cardiomyocytes. Br J Pharmacol 141(2):329-339

45. Navarro A, Zapata R, Canela EI, Mallol J, Lluis C, Franco R (1999) Epidermal growth factor (EGF)-induced up-regulation and agonistand antagonist-induced desensitization and internalization of $A_{1}$ adenosine receptors in a pituitary-derived cell line. Brain Res 816 (1):47-57 
46. Ciruela F, Saura C, Canela EI, Mallol J, Lluis C, Franco R (1997) Ligand-induced phosphorylation, clustering, and desensitization of $\mathrm{A}_{1}$ adenosine receptors. Mol Pharmacol 52(5):788-797

47. Alewijnse AE, Smit MJ, Hoffmann M, Verzijl D, Timmerman H, Leurs R (1998) Constitutive activity and structural instability of the wild-type human $\mathrm{H}_{2}$ receptor. J Neurochem 71(2):799-807

48. Van Schaick EA, Mathôt RA, Gubbens-Stibbe JM, Langemeijer MW, Roelen HC, IJzerman AP, Danhof M (1997) 8-Alkylaminosubstituted analogs of $\mathrm{N}^{6}$-cyclopentyladenosine are partial agonists for the cardiovascular adenosine $\mathrm{A}_{1}$ receptors in vivo. J Pharmacol Exp Ther 283(2):800-808

49. Van Schaick EA, Tukker HE, Roelen HC, IJzerman AP, Danhof M (1998) Selectivity of action of 8-alkylamino analogues of $\mathrm{N}^{6}$ cyclopentyladenosine in vivo: haemodynamic versus anti-lipolytic responses in rats. Br J Pharmacol 124(3):607-618

50. Wu L, Belardinelli L, Zablocki JA, Palle V, Shryock JC (2001) A partial agonist of the $\mathrm{A}_{1}$-adenosine receptor selectively slows $\mathrm{AV}$ conduction in guinea pig hearts. Am J Physiol Heart Circ Physiol 280(1):H334-343

51. Iacovelli L, Franchetti R, Grisolia D, De Blasi A (1999) Selective regulation of $\mathrm{G}$ protein-coupled receptor-mediated signaling by $G$ protein-coupled receptor kinase 2 in FRTL-5 cells: analysis of thyrotropin, $\alpha_{1 \mathrm{~B}}$-adrenergic, and $\mathrm{A}_{1}$ adenosine receptor-mediated responses. Mol Pharmacol 56(2):316-324

52. Saura C, Ciruela F, Casado V, Canela EI, Mallol J, Lluis C, Franco R (1996) Adenosine deaminase interacts with $\mathrm{A}_{1}$ adenosine receptors in pig brain cortical membranes. J Neurochem 66(4):1675-1682

53. Ciruela F, Saura C, Canela EI, Mallol J, Lluis C, Franco R (1996) Adenosine deaminase affects ligand-induced signalling by interacting with cell surface adenosine receptors. FEBS Lett 380(3):219-223

54. Gracia E, Cortes A, Meana JJ, Garcia-Sevilla J, Herhsfield MS, Canela EI, Mallol J, Lluis C, Franco R, Casado V (2008) Human adenosine deaminase as an allosteric modulator of human $\mathrm{A}_{1}$ adenosine receptor: abolishment of negative cooperativity for $\left[{ }^{3} \mathrm{H}\right]$ (R)-PIA binding to the caudate nucleus. J Neurochem 107(1):161170

55. Sarrio S, Casado V, Escriche M, Ciruela F, Mallol J, Canela EI, Lluis C, Franco R (2000) The heat shock cognate protein hsc73 assembles with $A_{1}$ adenosine receptors to form functional modules in the cell membrane. Mol Cell Biol 20(14):5164-5174

56. Saura CA, Mallol J, Canela EI, Lluis C, Franco R (1998) Adenosine deaminase and $\mathrm{A}_{1}$ adenosine receptors internalize together following agonist-induced receptor desensitization. J Biol Chem 273(28):17610-17617

57. Ding Y, Li M, Zhang J, Li N, Xia Z, Hu Y, Wang S, Fan GH (2006) The $73-\mathrm{kDa}$ heat shock cognate protein is a CXCR4 binding protein that regulates the receptor endocytosis and the receptor-mediated chemotaxis. Mol Pharmacol 69(4):12691279

58. Gines S, Ciruela F, Burgueno J, Casado V, Canela EI, Mallol J, Lluis C, Franco R (2001) Involvement of caveolin in ligand-induced recruitment and internalization of $\mathrm{A}_{1}$ adenosine receptor and adenosine deaminase in an epithelial cell line. Mol Pharmacol 59 (5):1314-1323

59. Escriche M, Burgueno J, Ciruela F, Canela EI, Mallol J, Enrich C, Lluis C, Franco R (2003) Ligand-induced caveolae-mediated internalization of $\mathrm{A}_{1}$ adenosine receptors: morphological evidence of endosomal sorting and receptor recycling. Exp Cell Res 285 (1):72-90

60. Garg V, Jiao J, Hu K (2009) Regulation of ATP-sensitive $\mathrm{K}^{+}$ channels by caveolin-enriched microdomains in cardiac myocytes. Cardiovasc Res 82(1):51-58

61. Lasley RD, Narayan P, Uittenbogaard A, Smart EJ (2000) Activated cardiac adenosine $A_{1}$ receptors translocate out of caveolae. J Biol Chem 275(6):4417-4421
62. Ballard-Croft C, Locklar AC, Keith BJ, Mentzer RM Jr, Lasley $\mathrm{RD}$ (2008) Oxidative stress and adenosine $\mathrm{A}_{1}$ receptor activation differentially modulate subcellular cardiomyocyte MAPKs. Am J Physiol Heart Circ Physiol 294(1):H263-271

63. Lu D, Yan H, Othman T, Turner CP, Woolf T, Rivkees SA (2004) Cytoskeletal protein $4.1 \mathrm{G}$ binds to the third intracellular loop of the $A_{1}$ adenosine receptor and inhibits receptor action. Biochem J 377(1):51-59

64. Ohno N, Terada N, Tanaka J, Yokoyama A, Yamakawa H, Fujii Y, Baba T, Ohara O, Ohno S (2005) Protein $4.1 \mathrm{G}$ localizes in rodent microglia. Histochem Cell Biol 124(6):477-486

65. Kull B, Svenningsson P, Fredholm BB (2000) Adenosine $A_{2 A}$ receptors are colocalized with and activate $G_{\text {olf }}$ in rat striatum. Mol Pharmacol 58(4):771-777

66. Van Calker D, Müller M, Hamprecht B (1979) Adenosine regulates via two different types of receptors, the accumulation of cyclic AMP in cultured brain cells. J Neurochem 33(5):999 1005

67. Offermanns S, Simon MI (1995) $\mathrm{G} \alpha_{15}$ and $\mathrm{G} \alpha_{16}$ couple a wide variety of receptors to phospholipase C. J Biol Chem 270 (25):15175-15180

68. Klinger M, Kudlacek O, Seidel MG, Freissmuth M, Sexl V (2002) MAP kinase stimulation by cAMP does not require RAP1 but SRC family kinases. J Biol Chem 277(36):32490 32497

69. Seidel MG, Klinger M, Freissmuth M, Holler C (1999) Activation of mitogen-activated protein kinase by the $\mathrm{A}_{2 \mathrm{~A}}$-adenosine receptor via a rap1-dependent and via a $\mathrm{p} 21^{\text {ras }}$-dependent pathway. J Biol Chem 274(36):25833-25841

70. Sexl V, Mancusi G, Holler C, Gloria-Maercker E, Schutz W, Freissmuth M (1997) Stimulation of the mitogen-activated protein kinase via the $\mathrm{A}_{2 \mathrm{~A}}$-adenosine receptor in primary human endothelial cells. J Biol Chem 272(9):5792-5799

71. Che J, Chan ES, Cronstein BN (2007) Adenosine $A_{2 A}$ receptor occupancy stimulates collagen expression by hepatic stellate cells via pathways involving protein kinase A, Src, and extracellular signal-regulated kinases $1 / 2$ signaling cascade or p38 mitogen-activated protein kinase signaling pathway. Mol Pharmacol 72(6):1626-1636

72. Burgueno J, Blake DJ, Benson MA, Tinsley CL, Esapa CT, Canela EI, Penela P, Mallol J, Mayor F Jr, Lluis C, Franco R, Ciruela F (2003) The adenosine $A_{2 A}$ receptor interacts with the actin-binding protein $\alpha$-actinin. J Biol Chem 278(39):37545-37552

73. Gsandtner I, Charalambous C, Stefan E, Ogris E, Freissmuth M, Zezula J (2005) Heterotrimeric G protein-independent signaling of a $\mathrm{G}$ protein-coupled receptor. Direct binding of ARNO/ cytohesin-2 to the carboxyl terminus of the $\mathrm{A}_{2 \mathrm{~A}}$ adenosine receptor is necessary for sustained activation of the ERK/MAP kinase pathway. J Biol Chem 280(36):31898-31905

74. Milojevic T, Reiterer V, Stefan E, Korkhov VM, Dorostkar MM, Ducza E, Ogris E, Boehm S, Freissmuth M, Nanoff C (2006) The ubiquitin-specific protease Usp4 regulates the cell surface level of the $\mathrm{A}_{2 \mathrm{~A}}$ receptor. Mol Pharmacol 69(4):1083-1094

75. Sun CN, Cheng HC, Chou JL, Lee SY, Lin YW, Lai HL, Chen HM, Chern Y (2006) Rescue of $p 53$ blockage by the $A_{2 A}$ adenosine receptor via a novel interacting protein, translin-associated protein X. Mol Pharmacol 70(2):454-466

76. Canela L, Lujan R, Lluis C, Burgueno J, Mallol J, Canela EI, Franco $\mathrm{R}$, Ciruela $\mathrm{F}$ (2007) The neuronal $\mathrm{Ca}^{2+}$-binding protein 2 (NECAB2) interacts with the adenosine $A_{2 A}$ receptor and modulates the cell surface expression and function of the receptor. Mol Cell Neurosci 36(1):1-12

77. Woods AS, Marcellino D, Jackson SN, Franco R, Ferre S, Agnati LF, Fuxe K (2008) How calmodulin interacts with the adenosine $\mathrm{A}_{2 \mathrm{~A}}$ and the dopamine $\mathrm{D}_{2}$ receptors. J Proteome Res 7 (8):3428-3434 
78. Keuerleber S, Gsandtner I, Freissmuth M (2010) From cradle to twilight: The carboxyl terminus directs the fate of the $\mathrm{A}_{2 \mathrm{~A}^{-}}$ adenosine receptor. Biochim Biophys Acta 1808(5):1350-1357

79. Klinger M, Kuhn M, Just H, Stefan E, Palmer T, Freissmuth M, Nanoff C (2002) Removal of the carboxy terminus of the $A_{2 A^{-}}$ adenosine receptor blunts constitutive activity: differential effect on cAMP accumulation and MAP kinase stimulation. NaunynSchmiedeberg's Arch Pharmacol 366(4):287-298

80. Li Q, Ye K, Blad CC, den Dulk H, Brouwer J, IJzerman AP, Beukers MW (2007) ZM241385, DPCPX, MRS1706 are inverse agonists with different relative intrinsic efficacies on constitutively active mutants of the human adenosine $\mathrm{A}_{2 \mathrm{~B}}$ receptor. J Pharmacol Exp Ther 320(2):637-645

81. Charalambous C, Gsandtner I, Keuerleber S, Milan-Lobo L, Kudlacek O, Freissmuth M, Zezula J (2008) Restricted collision coupling of the $\mathrm{A}_{2 \mathrm{~A}}$ receptor revisited: evidence for physical separation of two signaling cascades. J Biol Chem 283 (14):9276-9288

82. Braun S, Levitzki A (1979) Adenosine receptor permanently coupled to turkey erythrocyte adenylate cyclase. Biochemistry 18(10):2134-2138

83. Wirkner K, Assmann H, Koles L, Gerevich Z, Franke H, Norenberg W, Boehm R, Illes P (2000) Inhibition by adenosine $\mathrm{A}_{2 \mathrm{~A}}$ receptors of NMDA but not AMPA currents in rat neostriatal neurons. Br J Pharmacol 130(2):259-269

84. Navarro G, Aymerich MS, Marcellino D, Cortes A, Casado V, Mallol J, Canela EI, Agnati L, Woods AS, Fuxe K, Lluis C, Lanciego JL, Ferre S, Franco R (2009) Interactions between calmodulin, adenosine $\mathrm{A}_{2 \mathrm{~A}}$, and dopamine $\mathrm{D}_{2}$ receptors. J Biol Chem 284(41):28058-28068

85. Hillion J, Canals M, Torvinen M, Casado V, Scott R, Terasmaa A, Hansson A, Watson S, Olah ME, Mallol J, Canela EI, Zoli M, Agnati LF, Ibanez CF, Lluis C, Franco R, Ferre S, Fuxe K (2002) Coaggregation, cointernalization, and codesensitization of adenosine $\mathrm{A}_{2 \mathrm{~A}}$ receptors and dopamine $\mathrm{D}_{2}$ receptors. J Biol Chem 277 (20):18091-18097

86. Cheng HC, Shih HM, Chern Y (2002) Essential role of cAMPresponse element-binding protein activation by $\mathrm{A}_{2 \mathrm{~A}}$ adenosine receptors in rescuing the nerve growth factor-induced neurite outgrowth impaired by blockage of the MAPK cascade. J Biol Chem 277(37):33930-33942

87. Sun CN, Chuang HC, Wang JY, Chen SY, Cheng YY, Lee CF, Chern $Y$ (2010) The $A_{2 A}$ adenosine receptor rescues neuritogenesis impaired by $\mathrm{p} 53$ blockage via KIF2A, a kinesin family member. Dev Neurobiol 70(8):604-621

88. Linden J, Thai T, Figler H, Jin X, Robeva AS (1999) Characterization of human $A_{2 B}$ adenosine receptors: radioligand binding, western blotting, and coupling to $G_{q}$ in human embryonic kidney 293 cells and HMC-1 mast cells. Mol Pharmacol 56(4):705-713

89. Gao Z, Chen T, Weber MJ, Linden J (1999) $\mathrm{A}_{2 \mathrm{~B}}$ adenosine and $\mathrm{P} 2 \mathrm{Y}_{2}$ receptors stimulate mitogen-activated protein kinase in human embryonic kidney-293 cells. cross-talk between cyclic AMP and protein kinase c pathways. J Biol Chem 274(9):5972-5980

90. Feoktistov I, Biaggioni I (1995) Adenosine $A_{2 B}$ receptors evoke interleukin-8 secretion in human mast cells. An enprofylline-sensitive mechanism with implications for asthma. J Clin Invest 96(4):19791986

91. Mirabet M, Mallol J, Lluis C, Franco R (1997) Calcium mobilization in Jurkat cells via $\mathrm{A}_{2 \mathrm{~B}}$ adenosine receptors. $\mathrm{Br} \mathrm{J}$ Pharmacol 122(6): 1075-1082

92. Schulte G, Fredholm BB (2003) The $G_{s}$-coupled adenosine $A_{2 B}$ receptor recruits divergent pathways to regulate ERK1/2 and p38. Exp Cell Res 290(1):168-176

93. Fang Y, Olah ME (2007) Cyclic AMP-dependent, protein kinase A-independent activation of extracellular signal-regulated kinase
$1 / 2$ following adenosine receptor stimulation in human umbilical vein endothelial cells: role of exchange protein activated by cAMP 1 (Epac1). J Pharmacol Exp Ther 322(3):1189-1200

94. Corset V, Nguyen-Ba-Charvet KT, Forcet C, Moyse E, Chedotal A, Mehlen P (2000) Netrin-1-mediated axon outgrowth and cAMP production requires interaction with adenosine $\mathrm{A}_{2 \mathrm{~B}}$ receptor. Nature 407(6805):747-750

95. Rodrigues S, De Wever O, Bruyneel E, Rooney RJ, Gespach C (2007) Opposing roles of netrin-1 and the dependence receptor DCC in cancer cell invasion, tumor growth and metastasis. Oncogene 26(38):5615-5625

96. Stein E, Zou Y, Poo M, Tessier-Lavigne M (2001) Binding of DCC by netrin-1 to mediate axon guidance independent of adenosine $A_{2 B}$ receptor activation. Science 291(5510):19761982

97. Rosenberger P, Schwab JM, Mirakaj V, Masekowsky E, Mager A, Morote-Garcia JC, Unertl K, Eltzschig HK (2009) Hypoxia-inducible factor-dependent induction of netrin-1 dampens inflammation caused by hypoxia. Nat Immunol 10(2):195-202

98. McKenna WL, Wong-Staal C, Kim GC, Macias H, Hinck L, Bartoe JL (2008) Netrin-1-independent adenosine $A_{2 B}$ receptor activation regulates the response of axons to netrin- 1 by controlling cell surface levels of UNC5A receptors. J Neurochem 104(4):1081-1090

99. Martin M, Simon-Assmann P, Kedinger M, Mangeat P, Real FX, Fabre M (2006) DCC regulates cell adhesion in human colon cancer derived HT-29 cells and associates with ezrin. Eur J Cell Biol 85(8):769-783

100. Sitaraman SV, Wang L, Wong M, Bruewer M, Hobert M, Yun $\mathrm{CH}$, Merlin D, Madara JL (2002) The adenosine $2 \mathrm{~b}$ receptor is recruited to the plasma membrane and associates with E3KARP and Ezrin upon agonist stimulation. J Biol Chem 277 (36):33188-33195

101. Mundell SJ, Matharu AL, Nisar S, Palmer TM, Benovic JL, Kelly E (2010) Deletion of the distal COOH-terminus of the $A_{2 B}$ adenosine receptor switches internalization to an arrestin-and clathrin-independent pathway and inhibits recycling. $\mathrm{Br} \mathrm{J}$ Pharmacol 159(3):518-533

102. Mundell SJ, Loudon RP, Benovic JL (1999) Characterization of $G$ protein-coupled receptor regulation in antisense mRNAexpressing cells with reduced arrestin levels. Biochemistry 38 (27):8723-8732

103. Mundell SJ, Matharu AL, Kelly E, Benovic JL (2000) Arrestin isoforms dictate differential kinetics of $\mathrm{A}_{2 \mathrm{~B}}$ adenosine receptor trafficking. Biochemistry 39(42):12828-12836

104. Wang L, Kolachala V, Walia B, Balasubramanian S, Hall RA, Merlin D, Sitaraman SV (2004) Agonist-induced polarized trafficking and surface expression of the adenosine $2 \mathrm{~b}$ receptor in intestinal epithelial cells: role of SNARE proteins. Am J Physiol Gastrointest Liver Physiol 287(5):G1100-1107

105. Herrera C, Casado V, Ciruela F, Schofield P, Mallol J, Lluis C, Franco R (2001) Adenosine $A_{2 B}$ receptors behave as an alternative anchoring protein for cell surface adenosine deaminase in lymphocytes and cultured cells. Mol Pharmacol 59(1):127-134

106. Palmer TM, Gettys TW, Stiles GL (1995) Differential interaction with and regulation of multiple G-proteins by the rat $\mathrm{A}_{3}$ adenosine receptor. J Biol Chem 270(28):16895-16902

107. Reshkin SJ, Guerra L, Bagorda A, Debellis L, Cardone R, Li $\mathrm{AH}$, Jacobson KA, Casavola V (2000) Activation of $\mathrm{A}_{3}$ adenosine receptor induces calcium entry and chloride secretion in $\mathrm{A}_{6}$ cells. J Membr Biol 178(2):103-113

108. Gessi S, Merighi S, Varani K, Leung E, Mac Lennan S, Borea PA (2008) The $A_{3}$ adenosine receptor: an enigmatic player in cell biology. Pharmacol Ther 117(1):123-140

109. Lee DK, Lanca AJ, Cheng R, Nguyen T, Ji XD, Gobeil F Jr, Chemtob S, George SR, O'Dowd BF (2004) Agonist-independent 
nuclear localization of the Apelin, angiotensin $\mathrm{AT}_{1}$, and bradykinin $\mathrm{B}_{2}$ receptors. J Biol Chem 279(9):7901-7908

110. Calebiro D, Nikolaev VO, Persani L, Lohse MJ (2010) Signaling by internalized G-protein-coupled receptors. Trends Pharmacol Sci 31(5):221-228

111. Kohno Y, Sei Y, Koshiba M, Kim HO, Jacobson KA (1996) Induction of apoptosis in HL-60 human promyelocytic leukemia cells by adenosine $\mathrm{A}_{3}$ receptor agonists. Biochem Biophys Res Commun 219(3):904-910

112. Gao Z, Li BS, Day YJ, Linden J (2001) $A_{3}$ adenosine receptor activation triggers phosphorylation of protein kinase $B$ and protects rat basophilic leukemia $2 \mathrm{H} 3$ mast cells from apoptosis. Mol Pharmacol 59(1):76-82

113. Hammarberg C, Schulte G, Fredholm BB (2003) Evidence for functional adenosine $\mathrm{A}_{3}$ receptors in microglia cells. J Neurochem 86(4):1051-1054

114. Merighi S, Benini A, Mirandola P, Gessi S, Varani K, Leung E, Maclennan S, Borea PA (2005) $\mathrm{A}_{3}$ adenosine receptor activation inhibits cell proliferation via phosphatidylinositol 3-kinase/Aktdependent inhibition of the extracellular signal-regulated kinase $1 / 2$ phosphorylation in A375 human melanoma cells. J Biol Chem 280(20):19516-19526

115. Schulte G, Fredholm BB (2002) Signaling pathway from the human adenosine $A_{3}$ receptor expressed in Chinese hamster ovary cells to the extracellular signal-regulated kinase $1 / 2$. Mol Pharmacol 62(5):1137-1146

116. Morello S, Petrella A, Festa M, Popolo A, Monaco M, Vuttariello E, Chiappetta G, Parente L, Pinto A (2008) Cl-IB-MECA inhibits human thyroid cancer cell proliferation independently of $\mathrm{A}_{3}$ adenosine receptor activation. Cancer Biol Ther 7(2):278-284

117. Kim SG, Ravi G, Hoffmann C, Jung YJ, Kim M, Chen A, Jacobson KA (2002) p53-Independent induction of Fas and apoptosis in leukemic cells by an adenosine derivative, Cl-IB-MECA. Biochem Pharmacol 63(5):871-880
118. Lee K, Ravi G, Ji XD, Marquez VE, Jacobson KA (2001) RingConstrained (N)-methanocarba nucleosides as adenosine receptor agonists: independent 5 '-uronamide and 2'-deoxy modifications. Bioorg Med Chem Lett 11(10):1333-1337

119. Lu J, Pierron A, Ravid K (2003) An adenosine analogue, IBMECA, down-regulates estrogen receptor alpha and suppresses human breast cancer cell proliferation. Cancer Res 63(19):64136423

120. Yao Y, Sei Y, Abbracchio MP, Jiang JL, Kim YC, Jacobson KA (1997) Adenosine $A_{3}$ receptor agonists protect HL-60 and U-937 cells from apoptosis induced by $\mathrm{A}_{3}$ antagonists. Biochem Biophys Res Commun 232(2):317-322

121. Kim H, Kang JW, Lee S, Choi WJ, Jeong LS, Yang Y, Hong JT, Yoon do Y (2010) $A_{3}$ adenosine receptor antagonist, truncated Thio-Cl-IB-MECA, induces apoptosis in T24 human bladder cancer cells. Anticancer Res 30(7):2823-2830

122. Gao ZG, Jacobson KA (2008) Translocation of arrestin induced by human $\mathrm{A}_{3}$ adenosine receptor ligands in an engineered cell line: comparison with $\mathrm{G}$ protein-dependent pathways. Pharmacol Res 57(4):303-311

123. Graham S, Combes P, Crumiere M, Klotz KN, Dickenson JM (2001) Regulation of p42/p44 mitogen-activated protein kinase by the human adenosine $\mathrm{A}_{3}$ receptor in transfected $\mathrm{CHO}$ cells. Eur J Pharmacol 420(1):19-26

124. Santini F, Penn RB, Gagnon AW, Benovic JL, Keen JH (2000) Selective recruitment of arrestin-3 to clathrin coated pits upon stimulation of $G$ protein-coupled receptors. J Cell Sci 113 (Pt 13):2463-2470

125. Palmer TM, Stiles GL (2000) Identification of threonine residues controlling the agonist-dependent phosphorylation and desensitization of the rat $\mathrm{A}_{3}$ adenosine receptor. Mol Pharmacol 57(3):539-545

126. Peters MF, Scott CW (2009) Evaluating cellular impedance assays for detection of GPCR pleiotropic signaling and functional selectivity. J Biomol Screen 14(3):246-255 